\title{
Summer sea-ice variability on the Antarctic margin during the last glacial period reconstructed from snow petrel (Pagodroma nivea) stomach-oil deposits
}

\author{
Erin L. McClymont ${ }^{1}$, Michael J. Bentley ${ }^{1}$, Dominic A. Hodgson ${ }^{2,1}$, Charlotte L. Spencer-Jones ${ }^{1}$, Thomas Wardley ${ }^{1}$, \\ Martin D. West ${ }^{1}$, Ian W. Croudace ${ }^{3}$, Sonja Berg ${ }^{4}$, Darren R. Gröcke ${ }^{5}$, Gerhard Kuhn ${ }^{6}$, Stewart S. R. Jamieson ${ }^{1}$, \\ Louise Sime ${ }^{2}$, and Richard A. Phillips ${ }^{2}$ \\ ${ }^{1}$ Department of Geography, Durham University, Durham, DH1 3LE, United Kingdom \\ ${ }^{2}$ British Antarctic Survey, Natural Environment Research Council, Cambridge, CB3 0ET, United Kingdom \\ ${ }^{3}$ Ocean and Earth Science, University of Southampton, National Oceanography Centre, \\ Southampton, SO14 3ZH, United Kingdom \\ ${ }^{4}$ Institute of Geology and Mineralogy, University of Cologne, 50674 Cologne, Germany \\ ${ }^{5}$ Department of Earth Science, Durham University, Durham, DH1 3LE, United Kingdom \\ ${ }^{6}$ Alfred-Wegener-Institut Helmholtz-Zentrum für Polar- und Meeresforschung, 27568 Bremerhaven, Germany
}

Correspondence: Erin L. McClymont (erin.mcclymont@ durham.ac.uk)

Received: 1 October 2021 - Discussion started: 4 October 2021

Revised: 18 January 2022 - Accepted: 20 January 2022 - Published: 2 March 2022

\begin{abstract}
Antarctic sea ice is a critical component of the climate system affecting a range of physical and biogeochemical feedbacks and supporting unique ecosystems. During the last glacial stage, Antarctic sea ice was more extensive than today, but uncertainties in geological (marine sediments), glaciological (ice core), and climate model reconstructions of past sea-ice extent continue to limit our understanding of its role in the Earth system. Here, we present a novel archive of past sea-ice environments from regurgitated stomach oils of snow petrels (Pagodroma nivea) preserved at nesting sites in Dronning Maud Land, Antarctica. We show that by combining information from fatty acid distributions and their stable carbon isotope ratios with measurements of bulk carbon and nitrogen stable isotopes and trace metal data, it is possible to reconstruct changing snow petrel diet within Marine Isotope Stage 2 (ca. 24.3-30.3 cal kyr BP). We show that, as today, a mixed diet of krill and fish characterizes much of the record. However, between 27.4 and $28.7 \mathrm{cal} \mathrm{kyr} \mathrm{BP}$ signals of krill almost disappear. By linking dietary signals in the stomach-oil deposits to modern feeding habits and foraging ranges, we infer the use by snow petrels of open-water habitats ("polynyas") in the sea ice during our interval of study. The periods when consumption of krill was reduced are in-
\end{abstract}

terpreted to correspond to the opening of polynyas over the continental shelf, which became the preferred foraging habitat. Our results show that extensive, thick, and multiyear sea ice was not always present close to the continent during the last glacial stage and highlight the potential of stomach-oil deposits as a palaeoenvironmental archive of Southern Ocean conditions.

\section{Introduction}

Antarctic sea ice is globally important: large seasonal fluctuations in its spatial extent influence planetary albedo, oceanatmosphere exchanges of heat and climatically active gases including $\mathrm{CO}_{2}$, and the formation of intermediate water masses and deep water masses which create the world's largest sink of heat and carbon (e.g. Ackley et al., 2015; Delille et al., 2014; Arrigo et al., 2008; Frölicher et al., 2011). Antarctic sea-ice extent is projected to decline by $16 \%-67 \%$ by 2100 depending on greenhouse gas emission scenarios, but with low confidence due to a wide range of model responses (Collins et al., 2013). 
The geological record offers an opportunity to set the relatively short $(\sim 50$ years $)$ instrumental observations of sea ice into a longer-term context. During the Last Glacial Maximum (LGM, 19-23 ka) (Tierney et al., 2020), the development of thick, multiyear, and more extensive sea ice is inferred from the disappearance of, or diagnostic changes in, assemblages of marine microfossils from many Southern Ocean sediment cores (e.g. Hillenbrand and Cortese, 2006; Grobe and Mackensen, 1993; Bonn et al., 1998; Lucchi et al., 2002; Gersonde et al., 2005; Benz et al., 2016; Collins et al., 2012; Allen et al., 2011). An expanded "sea-ice cap" is proposed to have increased deep-ocean storage of $\mathrm{CO}_{2}$ by limiting the air-sea gas exchange and by enhancing $\mathrm{CO}_{2}$ export through increased Antarctic Bottom Water production (e.g. Stephens and Keeling, 2000; Ferrari et al., 2014).

Antarctic sea-ice environments today are dynamic and complex at a range of temporal and spatial scales (Parkinson, 2019; Turner et al., 2020), and they include open waters within the sea-ice pack (polynyas), which span a large size range $\left(1000-\sim 400000 \mathrm{~km}^{2}\right.$; Arrigo and van Dijken, 2003), are poorly represented in models (Mohrmann et al., 2021), and yet impact ocean circulation, formation of sea ice, and air-sea gas exchange (Mohrmann et al., 2021; Morales Maqueda et al., 2004). A similarly complex picture has emerged for the last glacial period: in the Atlantic sector of the Southern Ocean, spanning the Weddell, Lazarev, and Scotia seas (Fig. 1) there is fragmentary empirical evidence for polynyas during and before the LGM, as detailed by intervals of high productivity or bottom-current activity in marine sediment cores, and occupation of nesting sites by seabirds that require open water within their foraging range (e.g. Smith et al., 2010; Sprenk et al., 2014; Mackensen et al., 1989; Thatje et al., 2008; Berg et al., 2019; Weber et al., 1994). Millennial-scale variability in the extent of the seasonal sea-ice zone has also been described (Collins et al., 2012; Gersonde et al., 2003; Rae et al., 2018), but large $(10 \%-20 \%)$ uncertainties remain in both models and geological datasets (Collins et al., 2012; Roche et al., 2012; Gersonde et al., 2003). Maximum summer sea-ice extent was likely reached at 30-22 ka (Collins et al., 2012; Gersonde et al., 2003; Allen et al., 2011; Xiao et al., 2016), raising the possibility that Southern Ocean sea ice-climate feedbacks were more important before the global LGM (Allen et al., 2011; Xiao et al., 2016).

Here, we investigate changes in the sea-ice environment during the time of proposed maximum sea-ice extent (30$22 \mathrm{ka}$ ) by analysing a sequence of preserved stomach oils of snow petrels (Pagodroma nivea). Although sometimes referred to as "Antarctic mumiyo" (e.g. Berg et al., 2019; Thor and Low, 2011), this is a misnomer because its biological origin is so different from the original use of "mumiyo", which was used to describe an organic, tar-like substance of unknown origin found in high-altitude rocks and caves, especially in Asia (Hiller et al., 1988, and references therein;
Aiello et al., 2011). We therefore refer to Antarctic "stomachoil deposits" here.

Progressive accumulation of regurgitated stomach oils at the entrance to snow petrel nests in rock crevices and scree slopes (e.g. Johansson and Thor, 2004) leads to stratified deposits which may span several millennia (Hiller et al., 1988; Wand and Hermichen, 2005; Hiller et al., 1995; Thor and Low, 2011; Berg et al., 2019). The deposits include a mixture of stomach oils, guano, aeolian dust, and other mineral matter (Berg et al., 2019). Snow petrels forage in open waters at the margins of, or amongst, the sea ice within a restricted range (several $100 \mathrm{~km}$ ) from their nesting sites (Delord et al., 2016; Marchant and Higgins, 1990). Snow petrels feed on fish, krill, and squid (Ainley et al., 1984; Delord et al., 2016), and the stomach oils preserve a biochemical fingerprint of these prey. For example, krill tend to have high abundances of $\mathrm{C}_{14: 0}, \mathrm{C}_{16: 0}$, and $\mathrm{C}_{18: 1}$ fatty acids and a variety of carotenoid pigments (e.g. Cripps et al., 1999; Färber Lorda and Ceccaldi, 2020), as well as $\mathrm{Cu}, \mathrm{Zn}$, and $\mathrm{Fe}$ (Rainbow, 1989; Palmer Locarnini and Presley, 1995; Liu et al., 2013), whereas squid and fish are dominated by $\mathrm{C}_{16: 0}$ and $\mathrm{C}_{18: 0}$ fatty acids, respectively (Lewis, 1966). The presence of $\mathrm{Cu}$ in crustaceans (including krill) is linked to hemocyanins in invertebrates (Bridges et al., 1983), which provide an alternative oxygen carrier to the hemoglobins of vertebrate blood. Stable isotope ratios provide useful proxies for trophic level $\left(\delta^{15} \mathrm{~N}\right)$ and foraging habitat $\left(\delta^{13} \mathrm{C}\right)$, enabling diet comparisons between snow petrels and other seabirds (Delord et al., 2016; Cherel et al., 2010; Steele, 2005; Phillips et al., 2011).

Here, we undertake elemental scans, organic geochemistry, and stable isotope analysis to investigate snow petrel diet during the last glacial stage from a stomach-oil deposit collected at the Untersee Oasis in central Dronning Maud Land (DML). Since snow petrels have a restricted foraging range during the breeding season (Delord et al., 2016), our analyses enable us to reconstruct changes in their diet and foraging habitat relatively close to the Antarctic margin (Fig. 1). In turn, we hypothesize that the biochemistry of the stomach-oil deposits provides diagnostic signatures of snow petrels foraging in sea ice over or beyond the continental shelf and in polynyas, offering novel insights into the evolution of sea-ice environments during the last glacial stage.

\section{Materials and methods}

\subsection{Untersee Oasis sequence WMM7 and its regional context}

The stomach-oil deposit WMM7 was collected during the GeoMaud expedition (1995-1996) from the Untersee Oasis $\left(71^{\circ} 21.6^{\prime} \mathrm{S}, 13^{\circ} 18.96^{\prime} \mathrm{E}\right)$ in DML (Fig. 1) (Wand and Hermichen, 2005). The deposit was retrieved from under a boulder on a steep slope west of the Untersee, ca. $320 \mathrm{~m}$ above the lake surface, at an elevation of $880 \mathrm{~m}$ above sea level. 


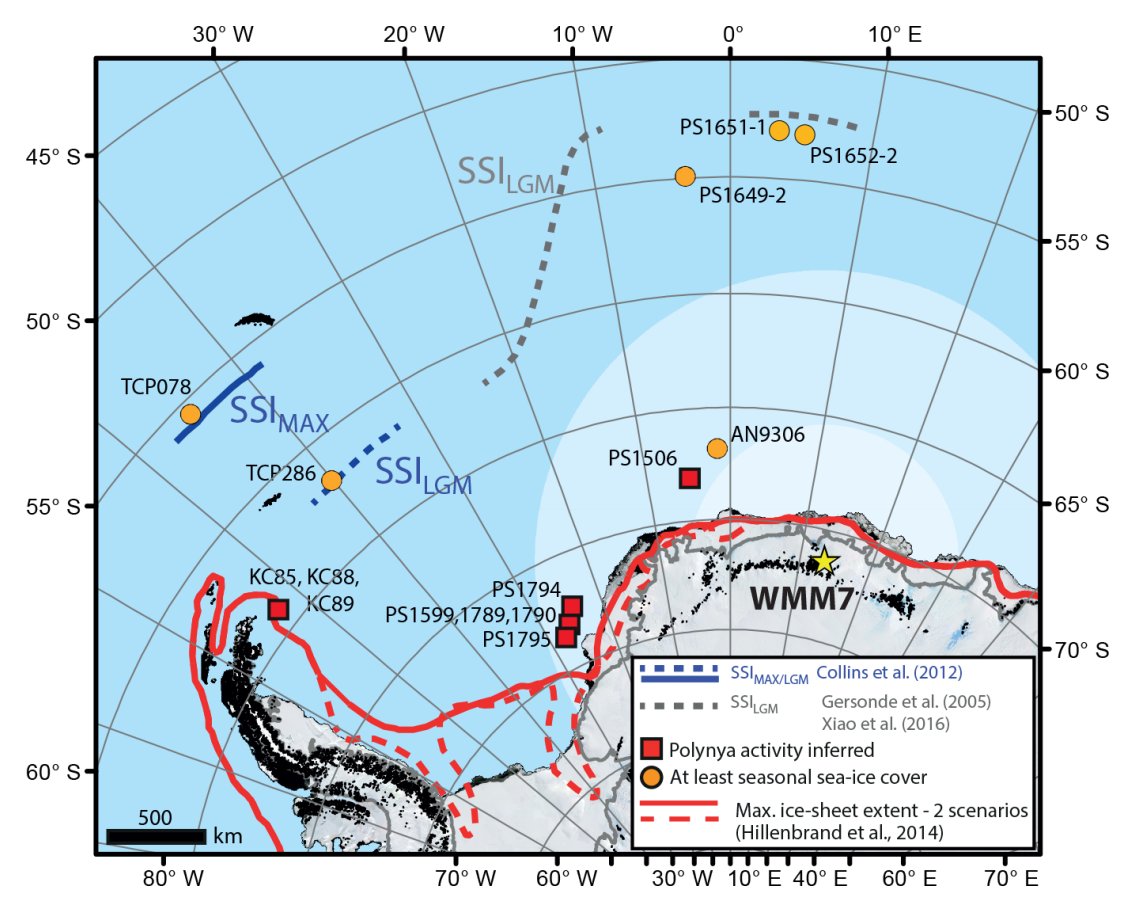

Figure 1. Sea-ice records of the last glacial stage for the Atlantic sector of the Southern Ocean. The stomach-oil deposit presented here (WMM7) is shown by the yellow star (Untersee Oasis; $71^{\circ} 22^{\prime} \mathrm{S}, 13^{\circ} 19^{\prime} \mathrm{E}$ ). The likely snow petrel foraging range is indicated by the shaded ellipse: although snow petrels can forage $2600 \pm 1000 \mathrm{~km}$ from their nests (pale shading) they are found in their highest densities within $700 \mathrm{~km}$ of the nest site during the breeding season (darker shading) (Delord et al., 2016). Boundaries of the maximum summer sea-ice extent (22-30 ka; Allen et al., 2011; Collins et al., 2012) and LGM summer sea-ice extent (19-23 ka; Gersonde et al., 2005; Xiao et al., 2016) are marked. Sites where polynya activity has been inferred for the last glacial stage are shown in red (Bonn et al., 1998; Smith et al., 2010; Sprenk et al., 2014; Weber et al., 1994), noting that the KC sites (Smith et al., 2010) and south-eastern Weddell Sea sites (PS1599, 1789, 1790, and 1974; Weber et al., 1994; and PS1795; Sprenk et al., 2014) infer polynyas opening "upstream" of the core locations. Note that the continental shelf edge is effectively also delineated by the solid red line of LGM maximum ice-sheet extent.

WMM7 was kept in dark, cold storage $\left(4^{\circ} \mathrm{C}, 60 \%\right.$ humidity) at the Alfred Wegener Institute, Germany, until analysis. The sample had a waxy consistency, so to preserve its internal structure it was frozen immediately before slicing and subsampling at Durham University. A central slab of WMM7 was sectioned for non-destructive, high-resolution X-ray fluorescence (XRF) analysis $(40 \mathrm{~mm}$ thick, $50 \mathrm{~mm}$ wide, and $150 \mathrm{~mm}$ long; marked in Fig. 2a). Samples for stable isotope and lipid analysis were taken adjacent to the XRF slab (Fig. 2a).

Before subsampling, WMM7 weighed ca. $1 \mathrm{~kg}$ and was $155-194 \mathrm{~mm}$ thick, $144 \mathrm{~mm}$ wide, and $120 \mathrm{~mm}$ deep (Fig. 2a). It had an irregular, mammillated outer surface but was characterized internally by millimetre-scale laminae that were traced through the deposit. The laminae visibly slope away from the centre of the deposit, showing that the deposit progressively draped over the underlying rock. Three distinct units were observed in the sequence during sampling (Fig. 2b): the oldest part of the sequence (160-110 mm depth, Unit III) was characterized by laminated, yellowbrown deposits overlain by a zone of relatively dark, brownblack deposits with more poorly defined laminae (Unit II). The Unit II-I transition was gradual $(80-70 \mathrm{~mm})$, and Unit I contained yellow-brown deposits with sub-millimetre-scale laminae (Unit I). No hiatuses were visible in the stratigraphy; these would be indicated by breaks in the structure or visible sediment, which would have been deposited and concentrated during an interval when stomach oils were not being deposited. The linear age model (Fig. 2) also indicated continuous accumulation.

\subsection{Radiocarbon analysis}

Previous ${ }^{14} \mathrm{C}$ analysis of the top of WMM7 provided an age constraint of $21551 \pm 110$ years (Berg et al., 2019). To establish an age-depth model, six additional bulk samples were dated (Table 1), and linear interpolation was applied between dating points. Each sample was digested in $2 \mathrm{M} \mathrm{HCl}\left(80^{\circ} \mathrm{C}\right.$, $8 \mathrm{~h}$ ), washed free from mineral acid with deionized water, and then dried. Samples were graphitized using an automated graphitization system (Rethermeyer et al., 2019) and analysed for ${ }^{14} \mathrm{C}$ by accelerator mass spectrometry (AMS) at CologneAMS, Germany. Radiocarbon ages were converted to calendar ages (Table 1) using the MARINE20 radiocarbon age calibration (Heaton et al., 2020) by adopting two approaches to explore the potential influence of changing sea- 


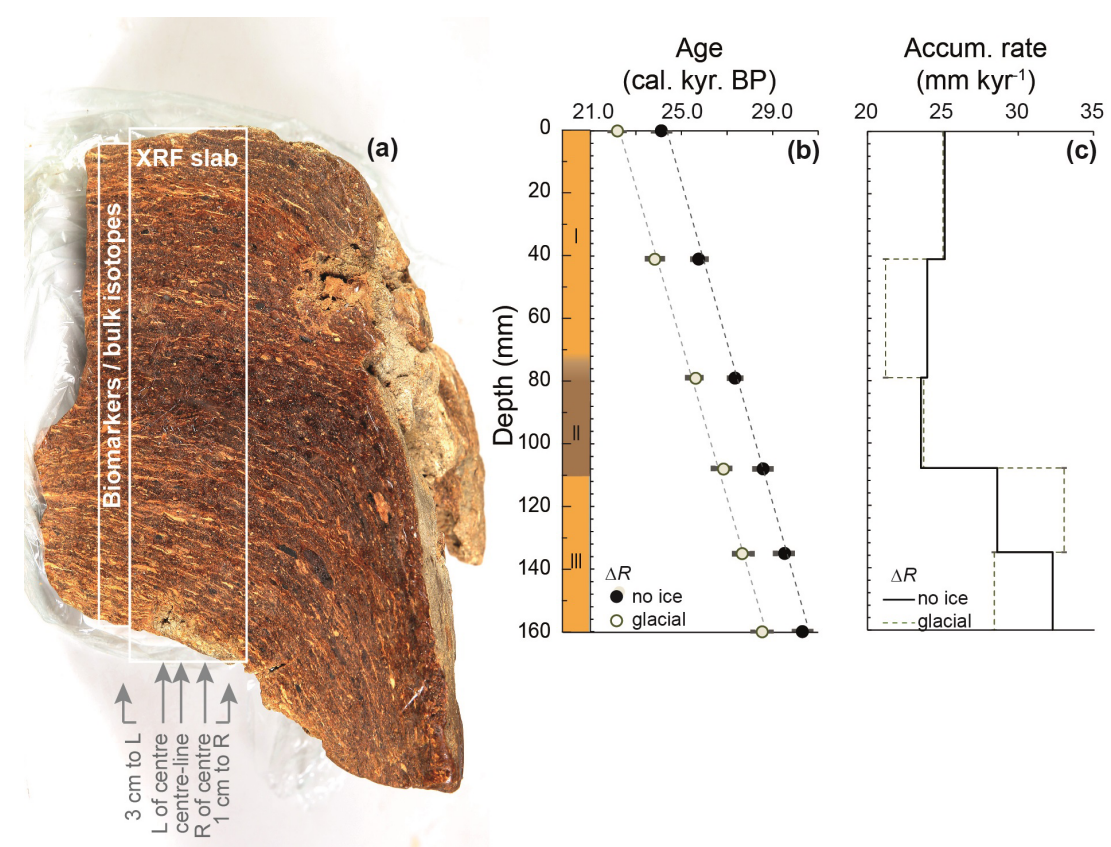

Figure 2. Stomach-oil deposit WMM7 stratigraphy and the two age-depth models explored in Sect. 2.2 and Table 1. (a) Cross-section of the section used for subsampling, scaled with panels (b) and (c). Note the clear laminae, which slope to the right away from the main slab. A zone of darker brown and less well-defined laminae is found in the central section (Unit II in panel b). A $5 \mathrm{~cm}$ wide slab was cut for XRF analysis. Data from the centreline scan are shown in Fig. 3 and used for statistical analysis. The results of additional scans to the left and right of centre and from two new cuts $(3 \mathrm{~cm}$ left, $3 \mathrm{~cm}$ right; see arrows) are shown in Fig. A1. Biomarker and bulk stable isotope samples were taken immediately to the left of the XRF slab. (b) Three-unit stratigraphy and two age-depth models constrained by six bulk radiocarbon dates, calibrated using either a Holocene "no sea ice" $\Delta R$ or a glacial-stage "maximum sea ice" $\Delta R$ (see Table 1 for ${ }^{14} \mathrm{C}$ calibration). Figures 3-6 apply the Holocene "no ice" $\Delta R$ age model; (c) accumulation rate between age control points for the two age-model scenarios. Linear interpolation was applied to generate an age-depth model for all sampling points.

ice extent on $\Delta R$ (Heaton et al., 2021). First, radiocarbon ages were corrected for the Southern Ocean marine reservoir effect by applying a $\Delta R$ of $670 \pm 50$ years from pre-bomb ${ }^{14} \mathrm{C}$ ages at Hope Bay in the western Weddell Sea (Björck et al., 1991). As this $\Delta R$ reflects Holocene conditions, wherein sea ice is low or absent from the region, this calibration is described as a "no sea ice" scenario (Table 1; Heaton, 2021). As variable sea-ice extent introduces additional uncertainty to radiocarbon age calibration in polar regions (Heaton et al., 2020), a second scenario was explored by applying a modelled glacial-stage maximum sea ice $\Delta R$ of $2480 \pm 50$ years (Table 1). As snow petrels forage in surface waters within sea ice or close to the sea-ice edge, we suggest that the glacialstage $\Delta R$ is likely an overestimate. For the results presented here, the datasets are described according to the Holocene "no sea ice" age model (Table 1), recognizing that this provides a maximum age for the WMM7 record. This approach also ensures that our results can be incorporated into studies using stomach-oil deposits for constraining ice-sheet thinning histories, for which they are used to indicate the onset of ice-free conditions (e.g. Hiller et al., 1988; Hillenbrand et al., 2014, and references therein). However, we acknowledge that the application of a constant, modern $\Delta R$ to a region af- fected by greater sea-ice extent during MIS 2 leads to larger uncertainty and potential bias in our calendar ages than indicated by the results in Table 1 (Heaton et al., 2020, 2021).

\subsection{XRF analysis}

XRF analysis was performed using the ITRAX core scanner at the National Oceanography Centre, Southampton, UK (Croudace et al., 2006). A molybdenum X-ray source was used $(45 \mathrm{kV}, 40 \mathrm{~mA})$ at a step size of $200 \mu \mathrm{m}$ and exposure time of $400 \mathrm{~s}$ per increment. To test for potential contamination during subsampling and to explore internal consistency of the recovered signals, a further five profiles were measured on the central slab (Figs. 2a, A1). Multiple XRF scans confirmed that the major patterns outlined below are consistently recorded in WMM7, with differences accounted for by changes in the orientation and spatial continuity of the laminae (Fig. A1).

\subsection{Bulk organic matter elemental composition and stable isotope analysis}

Directly adjacent to the left margin of the XRF slab, 15 contiguous $10 \mathrm{~mm}$ subsamples were taken by scalpel for bulk 
Table 1. Radiocarbon dates and calibrated ages. All ${ }^{14} \mathrm{C}$ analyses were performed on bulk samples at CologneAMS, Germany. COL3022 was previously published (Berg et al., 2019). All calibrations to calendar ages used MARINE20 (Heaton et al., 2020). To explore the likely range of impacts of sea ice on our ${ }^{14} \mathrm{C}$ calibrations, we first apply the nearest Holocene $\Delta R$ of $670 \pm 50$ years (Björck et al., 1991), which assumes low or absent sea ice sampled by WMM7 $\left(\Delta R^{\text {Holocene }}\right)$. A second calibration $\left(\Delta R^{\text {glacial stage }}\right)$ assumes enhanced sea-ice cover, as suggested for the last glacial stage, generated by adding 1800 years of additional ocean ${ }^{14} \mathrm{C}$ depletion as suggested by Heaton et al. (2020, 2021).

\begin{tabular}{|c|c|c|c|c|c|c|c|c|}
\hline $\begin{array}{l}\text { Depth } \\
(\mathrm{mm})\end{array}$ & Unit & $\begin{array}{l}\text { AMS lab } \\
\text { ID }\end{array}$ & $\begin{array}{r}\text { Median } \\
\text { age } \\
\left({ }^{14} \mathrm{C} \text { years }\right. \\
\mathrm{BP})\end{array}$ & $\begin{array}{r} \pm \\
\left({ }^{14} \mathrm{C} \text { years }\right. \\
\mathrm{BP})\end{array}$ & $\begin{array}{r}\text { Calibrated age } \\
\text { (cal. years } \mathrm{BP} \text { ), } \\
\Delta R^{\text {Holocene }} \\
670 \pm 50 \text { years }\end{array}$ & $\begin{array}{l}\text { Calibrated } \\
\text { range }(2 \sigma)\end{array}$ & $\begin{array}{c}\text { Calibrated age } \\
\text { (cal. years BP), } \\
\Delta R^{\text {glacial stage }} \\
2470 \pm 50 \text { years }\end{array}$ & $\begin{array}{l}\text { Calibrated } \\
\text { range }(2 \sigma)\end{array}$ \\
\hline 0 & I & COL3022 & 21550 & 110 & 23987 & $23668-24366$ & 22061 & $21736-22358$ \\
\hline 0 & I & COL4327 & 21660 & 104 & 24124 & $23758-24495$ & 22171 & $21859-22492$ \\
\hline 40 & I & COL4326 & 23170 & 114 & 25760 & $25488-26091$ & 23810 & $23502-24167$ \\
\hline 79 & $\mathrm{I} / \mathrm{II}$ & COL4328 & 24790 & 115 & 27350 & $27093-27614$ & 25603 & $25263-25868$ \\
\hline 108 & II/III & COL4329 & 25980 & 133 & 28585 & $28215-28938$ & 26825 & $26389-27126$ \\
\hline 135 & III & COL4325 & 26920 & 149 & 29531 & $29116-29867$ & 27642 & $27266-28057$ \\
\hline 160 & III & COL4324 & 27730 & 148 & 30307 & $29949-30685$ & 28522 & $28105-28912$ \\
\hline
\end{tabular}

stable isotope analysis (Fig. 2a). Carbon and nitrogen stable isotope analyses were performed using a Costech elemental analyser (ECS 4010) connected to a Thermo Scientific Delta $\mathrm{V}$ Advantage isotope ratio mass spectrometer. Carbon isotope ratios are corrected for ${ }^{17} \mathrm{O}$ and reported in standard delta $(\delta)$ notation in per mil $(\% o)$ relative to Vienna PeeDee Belemnite (VPDB). Nitrogen isotope ratios are reported against atmospheric nitrogen (AIR). Isotopic accuracy was monitored through multiple daily analysis of international (e.g. IAEA-600, IAEA-CH-3, IAEA-CH6, IAEA-N-1, IAEA-N-2, NBS 19, USGS24, USGS40) and in-house standards, which provided a linear range for $\delta^{13} \mathrm{C}$ between $-46 \%$ and $+3 \%$ and for $\delta^{15} \mathrm{~N}$ between $-4.5 \%$ o and $+20.4 \%$. Analytical uncertainty was typically $\pm 0.1 \%$ o (2 SD) for replicate analyses of the international standards and $<0.2 \%$ (2SD) on replicate sample analysis. Total organic carbon (TOC) and nitrogen data were obtained as part of the isotopic analysis using the internal standard: glutamic acid (40.82 wt \% C, $9.52 \mathrm{wt} \% \mathrm{~N}$ ).

\subsection{Biomarker distributions and stable carbon isotope analysis}

A $2 \mathrm{~mm}$ stainless-steel dermal punch was used to extract samples for biomarker analysis from the same line as the bulk stable isotope samples (Fig. 2a), including triplicates at $1 \mathrm{~cm}$ depth and $8 \mathrm{~cm}$ depth. Lipids were extracted from $0.03-0.3 \mathrm{~g}$ of each sample using repeated ultra-sonication $(3 \times 10 \mathrm{~min})$ in $10 \mathrm{~mL}$ dichloromethane (DCM)-methanol (3:1), following addition of two internal standards of known concentration (androstanol, hexatriacontane). Ultrasonic extraction yielded between 16 and $43 \mathrm{mg}$ of total lipid extract.

An aliquot of the total lipid extract was dissolved in acetone and analysed by UV-Vis spectrophotometry using a Dionex HPLC Quaternary pump and photo-diode array de- tector (McClymont et al., 2007). A grass standard and blank acetone were injected regularly to monitor potential instrument drift. The relative absorbance at wavelengths characteristic of chlorophyll derivatives ("chlorins") and potential carotenoid derivatives, at 410, 435, and $665 \mathrm{~nm}$ (Jeffrey et al., 1997), was calculated for each sample:

$P \lambda=\frac{(A \lambda \times \mathrm{DF})}{M}$,

where $P \lambda$ is the relative magnitude of absorbance for a given wavelength (abs. $g^{-1}$ ), $A \lambda$ is the integrated area for that wavelength averaged over three repeat measurements, DF is the dilution factor (i.e. the aliquot of the total sample injected), and $M$ is the mass of material which was extracted. To take into account the potential influence of variable organic matter deposition or preservation, we also normalized all photosynthetic pigment absorbance to TOC content (generated from Sect. 2.4). There may be multiple sources of our target pigments (Jeffrey et al., 1997), so we refer to them as $\mathrm{P} 410, \mathrm{P} 435$, and P665 to identify the trends in absorbance for each specific wavelength.

The remaining extracts were saponified using $2 \mathrm{~mL} \mathrm{KOH}$ $(8 \%)$ in methanol $(95 \%)$ and heated for $2 \mathrm{~h}$ at $70^{\circ} \mathrm{C}$. Neutral lipids were extracted using hexane; the remaining extracts were acidified using $2 \mathrm{M} \mathrm{HCl}$, and the fatty acids were extracted using hexane. An internal standard of known concentration (heptadecanoic acid, $0.4 \mathrm{mg} \mathrm{mL}^{-1}$ ) was added to the fatty acid fractions before generating fatty acid methyl esters (FAMEs) by methylating with $3 \mathrm{~mL}$ methanol-HCl $(95: 5)$ for $12 \mathrm{~h}$ at $70^{\circ} \mathrm{C}$, then allowing it to cool to room to temperature. After adding $4 \mathrm{~mL}$ of DCM-rinsed $\mathrm{H}_{2} \mathrm{O}$ to each sample, FAMEs were recovered sequentially using hexane followed by hexane-dichloromethane $(4: 1)$ and pooled. FAME fractions were then taken to dryness in a stream of $\mathrm{N}_{2}$. The isotopic value of the methanol was determined through methy- 
lation of a phthalic acid with known isotopic value (Lee et al., 2017).

The FAMEs were identified and quantified with a Thermo Trace 1310 gas chromatograph linked to an ISQ LT single quadrupole mass spectrometer (GC-MS). Chromatographic separation was performed with a Restek Famewax $30 \mathrm{~m} \times 0.25 \mathrm{~mm} \times 0.25 \mu \mathrm{m}$ column. Sample extracts were injected $(0.8 \mu \mathrm{L})$ in $\mathrm{CT}$ split mode $(80: 1$ ratio) into a programmable temperature vaporizing (PTV) injector at $230^{\circ} \mathrm{C}$ with a constant helium carrier gas flow rate of $1.5 \mathrm{~mL} \mathrm{~min}^{-1}$. The oven temperature was initially set to $100^{\circ} \mathrm{C}$ for $3.0 \mathrm{~min}$, then ramped at $2{ }^{\circ} \mathrm{C} \mathrm{min}^{-1}$ to $230^{\circ} \mathrm{C}$, and held at $230^{\circ} \mathrm{C}$ for $10 \mathrm{~min}$. The transfer line temperature was set to $230^{\circ} \mathrm{C}$ and the ion volume temperature to $220^{\circ} \mathrm{C}$. A mass range of 38 to $600 \mathrm{~m} / z$ was scanned every $0.5 \mathrm{~s}$, giving at least 20 data points per compound peak. Samples were identified and quantified by comparison to a Supelco 37 component ME mix (CRM47885, Sigma-Aldrich) with peak area ratios calculated with reference to the peak area of the internal standard. Spectral confirmation was performed using a NIST EI reference library.

The carbon isotopic compositions $\left(\delta^{13} \mathrm{C}\right)$ of individual saturated FAMEs were determined on eight samples (22-132 mm depth) using a Thermo GC-C-IRMS system at the Department of Geography, Durham University. All samples were run in duplicate. The system was composed of a Trace 1310 GC coupled to a Thermo Delta V Plus via a GC IsoLink II and a Restek Famewax $30 \mathrm{~m} \times 0.25 \mathrm{~mm} \times 0.25 \mu \mathrm{m}$ column. Samples were injected $(2 \mu \mathrm{L})$ in splitless mode into an S/SL injector set to $240^{\circ} \mathrm{C}$ with a helium carrier gas flow rate of $1.5 \mathrm{~mL} \mathrm{~min}^{-1}$. The oven temperature was initially set to $50^{\circ} \mathrm{C}$ for $1 \mathrm{~min}$, then ramped to $100^{\circ} \mathrm{C}$ at $10^{\circ} \mathrm{C} \mathrm{min}^{-1}$, then ramped to $240^{\circ}$ at $3^{\circ} \mathrm{C} \mathrm{min}^{-1}$, and finally held for $10 \mathrm{~min}$ at $240^{\circ} \mathrm{C}$. The alumina (with $\mathrm{CuO}, \mathrm{NiO}$, and $\mathrm{Pt}$ wires) combustion reactor was operated at $1000^{\circ} \mathrm{C}$ and conditioned with oxygen each day immediately before use. $\mathrm{CO}_{2}$ reference gas pulses were introduced at the start and end of each chromatogram to provide an isotope ratio reference point and to check the system stability during the run. All the quantified FAME peaks in the selected carbon range were baseline-resolved apart from the cis- and trans-isomers of $\mathrm{C}_{18: 1}$. A FAME standard (CRM47885 - Supelco 37 component mix, Sigma-Aldrich) was run with each batch of isotope reference standards to confirm the retention time of the FAME peaks. Individual FAME isotope ratio values were corrected using a multipoint linear normalization of a $\mathrm{C}_{14}-\mathrm{C}_{20}$ FAME reference material (F8-3 standard provided by Arndt Schimmelmann, Indiana University, Bloomington). Reference standard FAMEs from $\mathrm{C}_{14}-\mathrm{C}_{20}$ were used to generate the normalization curve, covering $\delta^{13} \mathrm{C}$ values from $-23.24 \%$ to $-30.92 \%$ o. Reference material F8-3 was also used to determine the usable amplifier signal range, which minimized the residuals, and gave an $r^{2}$ value of at least 0.995 for the normalization plot. The concentration of the F8-3 FAME standard used for the linear normalization was adjusted to obtain reference amplifier intensities within this range (1000 to $6000 \mathrm{mV}$ ). Each sample was then diluted and pre-run to determine the optimum solvent volume required to fit within the amplifier signal range of the reference standards. The long-term pooled standard deviations of the ME F8-3 reference compounds were all $<0.35 \%$ o (ranging from $0.21 \%$ to $0.34 \%, n=21$ ). Fatty acid $\delta^{13} \mathrm{C}$ was calculated through mass balance corrections of the measured FAME $\delta^{13} \mathrm{C}$ and known $\delta^{13} \mathrm{C}$ of the added methyl group (Lee et al., 2017). It is reported relative to $\mathrm{Vi}$ enna PeeDee Belemnite (VPDB).

\subsection{Statistical analysis}

Principal component analysis (PCA) was performed to investigate the potential for co-evolving relationships in the stomach-oil geochemistry using the PAST3 software (Hammer et al., 2001). We focussed on the XRF data for PCA since it was analysed at the highest resolution and with the highest number of variables, and we used the variance-covariance matrix since all variables were measured in the same units (i.e. counts). Elements which consistently recorded counts below 500 were excluded from the analysis.

Cluster analysis was performed to identify units of similar geochemical composition using the rioja package in $\mathrm{R}$ 3.6.0 (Juggins, 2020), whereby a hierarchical clustering is performed, constrained by sample order, and compared to a broken-stick model of a random distribution of zones within a sequence (Bennett, 1996). Due to the different sampling resolutions of the geochemical methods employed here, we resampled the XRF data by averaging element counts across the same depth window sampled by each of the discrete geochemical measurements ( $10 \mathrm{~mm}$ diameter). This resampling approach does not alter the main signals of the principal components, although additional clusters are identified using the original XRF data (Fig. A2). We present the resampled XRF PCA here as an independent measure of geochemical change that is comparable to the resolution of the lipid distribution and stable isotope signatures.

\section{Results}

\subsection{WMM7 age model}

Stomach-oil deposit WMM7 spans $23987 \quad$ (2366824366) cal yr BP through 30307 (29949-30 685) cal yr BP using the Holocene "no sea ice" $\Delta R$ for calibration (Table 1). The unit transitions are well constrained by ${ }^{14} \mathrm{C}$ dates (Fig. 2b). The accumulation rate is remarkably stable at $26.6 \pm 3.7 \mathrm{~mm} \mathrm{cal} \mathrm{kyr}^{-1}$ (Fig. 2c).

\subsection{Elemental composition (XRF)}

Deposit WMM7 was dominated by $\mathrm{Fe}, \mathrm{Ca}, \mathrm{Cu}$, and Ti. Elements likely to be indicative of minerogenic inputs (e.g. Ti, 
$\mathrm{Al}, \mathrm{K}, \mathrm{Ca}$ ), for example from windblown particulates, had low signals overall (Fig. A3). There were no horizons of elevated minerogenic inputs, which might be expected during a hiatus in stomach-oil accumulation. Elements with both a biogenic and minerogenic (e.g. $\mathrm{Cu}, \mathrm{Fe}$ ) or principally biogenic source (e.g. As, Zn) (Huang et al., 2009; Liu et al., 2013) varied both at the millimetre-scale (likely reflecting individual laminae) and with depth in the deposit (Fig. A3). To account for the influence of minerogenic contributions to the elemental composition of WMM7, all data were normalized to Ti (Figs. 3, A4). There were no clear down-core trends in $\mathrm{Fe} / \mathrm{Ti}$ and $\mathrm{Si} / \mathrm{Ti}$ (Fig. 3a, b) indicating a dominant minerogenic source for $\mathrm{Fe}$ and $\mathrm{Si}$. $\mathrm{Cu} / \mathrm{Ti}$ was generally elevated at 30.3-28.6 ka with minima at ca. $29.3 \mathrm{ka}$ (Unit III) and very low values between 28.5 and $27.4 \mathrm{ka}$ (Unit II). The highest $\mathrm{Cu} / \mathrm{Ti}$ was recorded between 27.4 and $26.9 \mathrm{ka}$, then remained elevated until $25.7 \mathrm{ka}$ (Unit I), until values decreased to the top of the deposit (Fig. 3c). In contrast, $\mathrm{Br} / \mathrm{Ti}$ and $\mathrm{S} / \mathrm{Ti}$ were low from 30.3 to $28.7 \mathrm{ka}$ (Unit III), then elevated between 28.7 and $27.4 \mathrm{ka}$ (Unit II; Fig. 3d, e). A gradual increase in $\mathrm{Br} / \mathrm{Ti}$ and $\mathrm{S} / \mathrm{Ti}$ was then recorded until a second maximum at $25.5 \mathrm{ka}$ (Unit I); both $\mathrm{Br}$ and $\mathrm{S}$ then decreased to $24.5 \mathrm{ka}$. A dominant biogenic source for the trends in $\mathrm{Si}$, $\mathrm{Cu}, \mathrm{Br}$, and $\mathrm{S}$ is inferred for WMM7, noting that the patterns in $\mathrm{Br} / \mathrm{Ti}$ and $\mathrm{S} / \mathrm{Ti}$ were different to those of $\mathrm{Cu} / \mathrm{Ti}$ and may include a sea-salt origin given some similarities to $\mathrm{Cl} / \mathrm{Ti}$ (not shown; $r^{2}=0.36$ ).

The PCA of the XRF data confirms that there were two main patterns in the elemental composition of WMM7 (Fig. 3f, g; Table 2). PC1 accounted for $93 \%$ of the variance and is driven by positive loading from $\mathrm{Fe}, \mathrm{Cu}$, and $\mathrm{Ca}$, which could have both minerogenic and biogenic origins. PC2 accounted for $6 \%$ of the variance, driven by $\mathrm{Cu}$ (positive loading), $\mathrm{Ca}$, and $\mathrm{Fe}$ (negative loading), but PC2 was not a statistically significant factor using the broken-stick threshold in PAST3. Peaks in PC1 occurred before $28.5 \mathrm{ka}$ (Unit III), between 27.1 and $26.3 \mathrm{ka}$ (lower Unit I), and at 24.7 (uppermost Unit I). PC1 minima occurred in Unit II (28.5-27.6 ka) when high $\mathrm{Br} / \mathrm{Ti}$ and $\mathrm{S} / \mathrm{Ti}$ confirmed enhanced organic matter inputs. In contrast, PC2 broadly followed the $\mathrm{Cu} / \mathrm{Ti}$ trend, recording declining values from 29.9-27.6 ka (Units III and II) and peak values at $27.1 \mathrm{ka}$ (lower Unit I, Fig. 3). Three clusters were identified in the resampled XRF data (Fig. 3i), broadly aligned to Units I-III.

\subsection{Organic matter composition}

All WMM7 samples were highly organic-rich (27\%-50\% C, $11 \%-13 \%$ N, Fig. A5), with C / N ratios between 6 and 12 (Fig. 4a). The $\mathrm{C} / \mathrm{N}$ ratios were consistent with high lipid and low $\mathrm{N}$ contributions as observed in modern Weddell Sea fish, bird, and seal tissues (Rau et al., 1992). The extracted lipids were dominated by fatty acids and alcohols (not presented here), consistent with the presence of triglycerides and wax esters observed today in stomach oils of procellariform
Table 2. Principal component analysis. The elements contributing to each principal component are shown; bold font highlights $\mathrm{Fe}$, $\mathrm{Cu}$, and $\mathrm{Ca}$, which dominate the loadings. PC1 explains $93 \%$ of the variance (statistically significant), whereas PC2 explains only $6 \%$ of the variance and is not statistically significant. PC1 and PC2 through time are shown in Fig. 3.

\begin{tabular}{lrr}
\hline $\begin{array}{l}\text { Principal component } \\
\text { loadings }\end{array}$ & PC 1 & PC 2 \\
\hline $\mathrm{Si}$ & 0.003 & 0.001 \\
$\mathrm{P}$ & 0.001 & -0.002 \\
$\mathrm{~S}$ & 0.004 & -0.009 \\
$\mathrm{Cl}$ & 0.013 & -0.034 \\
$\mathrm{~K}$ & 0.028 & -0.051 \\
$\mathrm{Ca}$ & $\mathbf{0 . 1 6 2}$ & $\mathbf{- 0 . 1 6 5}$ \\
$\mathrm{Ti}$ & 0.026 & -0.019 \\
$\mathrm{Cr}$ & 0.004 & -0.003 \\
$\mathrm{Mn}$ & 0.010 & -0.006 \\
$\mathrm{Fe}$ & $\mathbf{0 . 9 6 1}$ & $\mathbf{- 0 . 1 8 1}$ \\
$\mathrm{Cu}$ & $\mathbf{0 . 2 1 7}$ & $\mathbf{0 . 9 6 2}$ \\
$\mathrm{Zn}$ & 0.008 & -0.005 \\
$\mathrm{Br}$ & 0.019 & -0.008 \\
$\mathrm{Rb}$ & 0.002 & -0.004 \\
$\mathrm{Sr}$ & 0.041 & -0.091 \\
$\mathrm{Zr}$ & 0.009 & -0.005 \\
\hline
\end{tabular}

seabirds, i.e. albatrosses and petrels (e.g. Horgan and Barrett, 1985). The saturated fatty acids $\mathrm{C}_{16: 0}(46 \pm 4 \%)$ and $\mathrm{C}_{14: 0}(24 \pm 1 \%)$ dominated all samples, with additional minor contributions from $\mathrm{C}_{18: 1}(16 \pm 3 \%), \mathrm{C}_{18: 0}(8 \pm 1 \%)$, and $\mathrm{C}_{16: 1}(5 \pm 1 \%)$ (Fig. 4b, c).

The dominant fatty acids in WMM7 are consistent with a snow petrel diet of krill $\left(\mathrm{C}_{14: 0}, \mathrm{C}_{16: 0}\right)$, squid $\left(\mathrm{C}_{16: 0}\right)$, and fish $\left(\mathrm{C}_{16: 0}, \mathrm{C}_{18: x}\right)$ (Cripps et al., 1999; Lewis, 1966) (Table 3). To explore whether prey contributions changed through time, the relative abundance of the major fatty acids were compared as ratios (Fig. $4 \mathrm{~d}-\mathrm{f}$ ), assuming a krill $\left(\mathrm{C}_{14: 0}\right)$, fish $\left(\mathrm{C}_{18: x}\right)$, or mixed source $\left(\mathrm{C}_{16: 0}\right)$ (Table 3$)$. Minor variations to $C_{18: 0} / C_{16: 0}$ occurred $(0.18 \pm 0.03$, not shown), whereas $\mathrm{C}_{18: 0} / \mathrm{C}_{18: 1}$ broadly decreased from 30.3 to $25.9 \mathrm{ka}$, then increased towards the top of the deposit (Fig. $4 d) . C_{16: 0} / C_{14: 0}$ values were generally low $(\sim 1.75)$ throughout the deposit but peaked at 29.1-28.8, 27.6, and $25.5 \mathrm{ka} . \mathrm{C}_{18: 0} / \mathrm{C}_{14: 0}$, broadly increased from $30.3-27.4 \mathrm{ka}$ (Units III and II), decreased between 27.4 and $25.9 \mathrm{ka}$ (lower Unit I), and then increased to reach a maximum at the top of the deposit ( $24.3 \mathrm{ka})$.

The major pigments in WMM7 were P410 and P435 (Fig. 4h), consistent with chlorophyll derivatives (chlorins; Harris and Maxwell, 1995) and some carotenoid sources (Jeffrey et al., 1997). P665, recording exclusively chlorins, was very low (3 orders of magnitude below P410, Fig. A5). P410 was elevated at 29.8-28.8 ka (Unit III) and showed a sustained maximum between 28.5 and $27.2 \mathrm{ka}$ (extending across the Unit II-I boundary, Fig. 4h). P435 remained low 


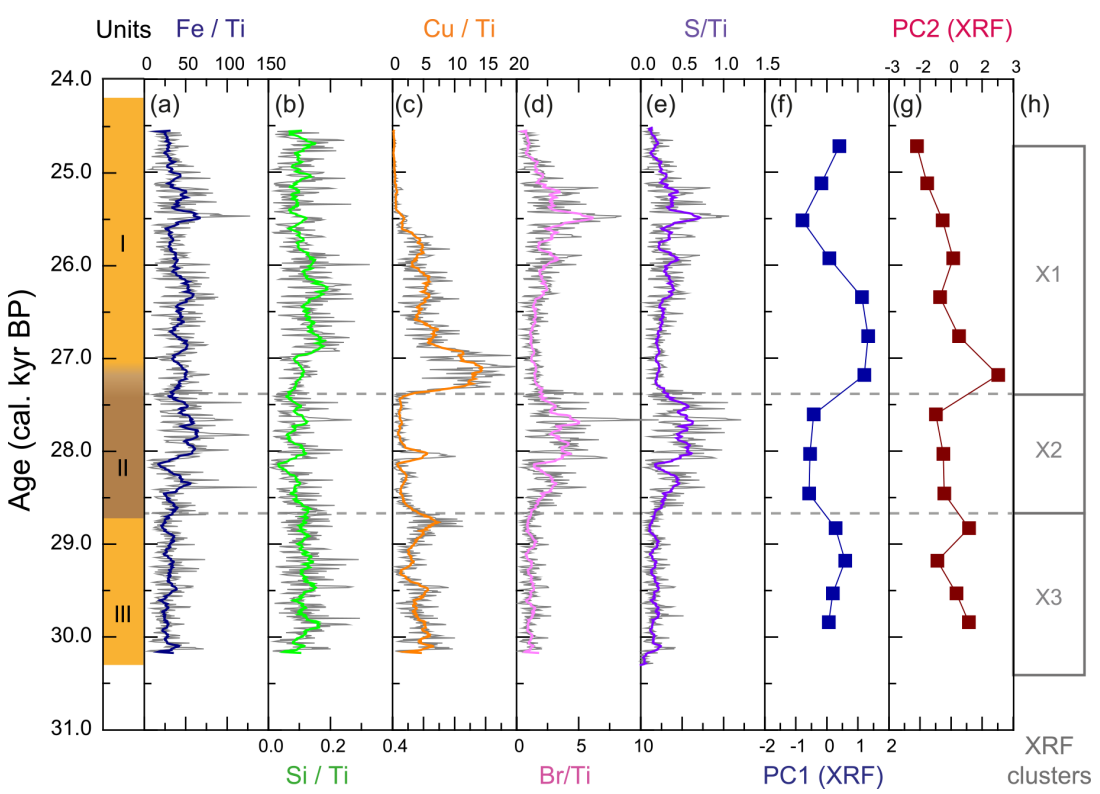

Figure 3. XRF characterization of stomach-oil deposit WMM7. All XRF data are normalized to Ti. The age model uses Holocene "no sea ice" $\Delta R$ (Table 1). The $\sim 100$-year smoothing is shown in coloured lines. Cluster boundaries are determined by constrained hierarchical clustering analysis in the rioja package of R (Juggins, 2020) compared to a broken-stick analysis (Bennett, 1996). Three significant clusters were identified (h), which broadly coincide with Units I-III, noting the gradual Unit II-I boundary.

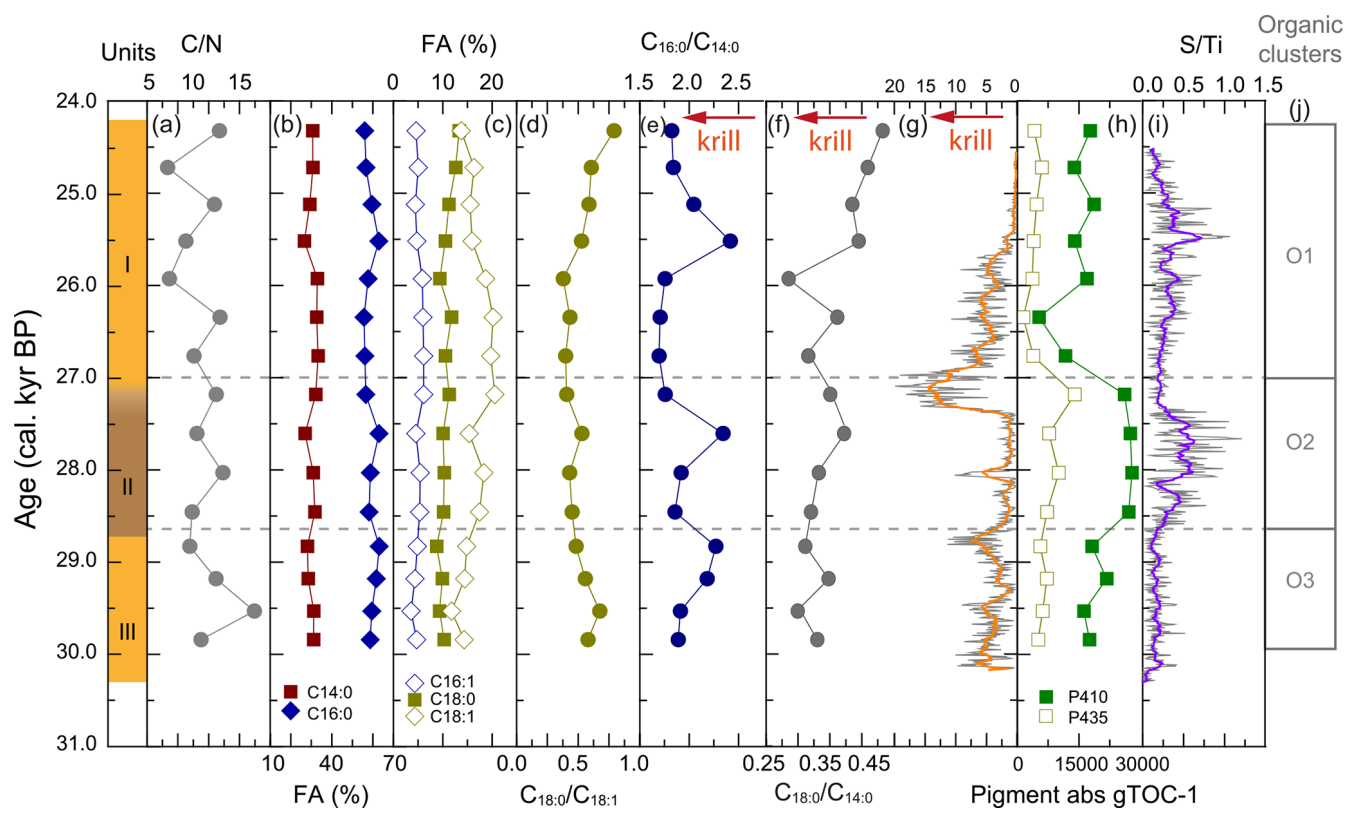

Figure 4. Organic matter composition of stomach-oil deposit WMM7. The age model uses Holocene "no sea ice" $\Delta R$ (Table 1). Unit II is highlighted with brown shading, noting the gradual Unit II-I boundary. Cluster boundaries are determined by constrained hierarchical clustering analysis in the rioja package of R (Juggins, 2020) compared to a broken-stick analysis (Bennett, 1996). Three significant clusters were identified (j), which broadly coincide with Units I-III, noting the gradual Unit II-I boundary. The Cu / Ti data from Fig. 3 are shown in (g), noting the reverse $x$ axis to align with the interpretation fatty acid indicators of krill in (e) and (f). 
Table 3. Examples of snow petrel prey biochemistry and oceanographic conditions related to snow petrel diet and prey distributions. Snow petrels forage in close association with the sea ice, either at the sea-ice edge or in leads or polynyas within the sea-ice pack. The prey biochemistry information is used as a framework to interpret the chemical signatures recorded in stomach-oil deposit WMM7, including our use of fatty acid ratios to assess relative contributions of prey (Figs. 4 and 5).

\begin{tabular}{|c|c|c|c|}
\hline Environment & Characteristics & $\begin{array}{l}\text { Expected signal recorded in stomach-oil deposit } \\
\text { and interpretation made here }\end{array}$ & References for prey biochemistry \\
\hline $\begin{array}{l}\text { Open } \\
\text { ocean } \\
\text { (pelagic) }\end{array}$ & $\begin{array}{l}\text { Mixed snow petrel diet: krill, } \\
\text { squid, and fish. Krill species: } E \text {. } \\
\text { superba (Antarctic krill). }\end{array}$ & $\begin{array}{l}\mathrm{C}_{14: 0}, \mathrm{C}_{16: 0}, \mathrm{C}_{18: 0} \text { fatty acids and } \mathrm{Cu} \text { (krill). } \\
\mathrm{C}_{16: 0} \text { fatty acids (squid). } \\
\mathrm{C}_{18: 0} \text { and } \mathrm{C}_{18: 1} \text { fatty acids (fish). } \\
\Rightarrow \text { low } \mathrm{C}_{16: 0} / \mathrm{C}_{14: 0} \text { (more krill) } \\
\Rightarrow \text { low } \mathrm{C}_{18: 0} / \mathrm{C}_{14: 0} \text { (more krill) } \\
\Rightarrow \text { high } \mathrm{Cu} \text { (more krill) }\end{array}$ & $\begin{array}{l}\text { Cripps et al. (1999), Lewis (1966), } \\
\text { Rainbow (1989), Palmer Lo- } \\
\text { carnini and Presley (1995), Liu et } \\
\text { al. (2013) }\end{array}$ \\
\hline $\begin{array}{l}\text { Continental } \\
\text { shelf } \\
\text { (neritic) }\end{array}$ & $\begin{array}{l}\text { More fish in snow petrel diet. } \\
\text { Potential for krill to include Eu- } \\
\text { phausia crystallorophias (ice } \\
\text { krill) as well as E. superba. }\end{array}$ & $\begin{array}{l}\text { Increased } \mathrm{C}_{18: 0} \text { and } \mathrm{C}_{18: 1} \text { fatty acids } \\
\Rightarrow \text { high } \mathrm{C}_{16: 0} / \mathrm{C}_{14: 0} \text { (less krill) } \\
\Rightarrow \text { high } \mathrm{C}_{18: 0} / \mathrm{C}_{14: 0} \text { (less krill) } \\
\Rightarrow \text { low } \mathrm{Cu} \text { (less krill) }\end{array}$ & $\begin{array}{l}\text { Bottino (1975), Imber (1976), } \\
\text { Raclot et al. (1998), Mayzaud et } \\
\text { al. (2011), Ju and Harvey (2004). }\end{array}$ \\
\hline
\end{tabular}

from the base of the sequence until a small peak at $27.2 \mathrm{ka}$. A rapid decrease in $\mathrm{P} 410$ and $\mathrm{P} 435$ resulted in pigment minima at $26.3 \mathrm{ka}$. From $25.9-24.3 \mathrm{ka}$, P410 oscillated at intermediate values, and there is a slight increase in P435 (Fig. 4h).

\subsection{Stable isotope composition}

Bulk $\delta^{13} \mathrm{C}$ ranged from $-27.0 \%$ to $-29.9 \%$. Bulk $\delta^{15} \mathrm{~N}$ ranged between $11.1 \%$ and $12.6 \%$. There was a positive correlation between $\delta{ }^{15} \mathrm{~N}_{\text {bulk }}$ and $\delta^{13} \mathrm{C}_{\text {bulk }}$ between 30.3 and $25.9 \mathrm{ka}$, but they were negatively correlated after $25.9 \mathrm{ka}$ (Fig. 5a, b). The two major fatty acids were offset from $\delta^{13} \mathrm{C}_{\text {bulk }}$ by up to $-5.8 \%$ ( $\left(-3.3 \pm 1.4 \%, \mathrm{C}_{14: 0}\right)$ and up to $-3.9 \%$ o ( $-1.3 \pm 1.6 \%$ o, $\mathrm{C}_{16: 0}$; Fig. 5c). The most enriched values were recorded by $\delta^{13} \mathrm{C}_{18: 1}(-26.0 \pm 1.2 \%$ ), which is offset to $\delta^{13} \mathrm{C}_{18: 0}$ by $+1.27 \pm 1.3 \%$ and to $\delta^{13} \mathrm{C}_{\text {bulk }}$ by $+2.1 \pm 1.6 \%$ o. Although lipid $\delta^{13} \mathrm{C}$ is usually depleted relative to $\delta^{13} \mathrm{C}_{\text {bulk }}$ as a result of fractionation during lipid synthesis (e.g. Rau et al., 1992), the dominance of lipids in WMM7 resulted in $\delta^{13} \mathrm{C}_{\text {bulk }}$ reflecting the combined influences of the main lipid components.

Fatty acid $\delta^{13} \mathrm{C}$ showed several short-term oscillations (Fig. 5c). Both $\delta^{13} \mathrm{C}_{16: 0}$ and $\delta^{13} \mathrm{C}_{14: 0}$ decreased from 29.4$28.4 \mathrm{ka}$ (Unit III, lower Unit II), whereas $\delta^{13} \mathrm{C}_{18: 0}$ increased and $\delta^{13} \mathrm{C}_{18: 1}$ showed no clear trend. All fatty acid $\delta^{13} \mathrm{C}$ values were low at $28.4 \mathrm{ka}$ (Unit II). The $\delta^{13} \mathrm{C}_{14: 0}$ remained low from 28.4-27.4 ka (Unit II), whereas $\delta^{13} \mathrm{C}_{16: 0}$ and $\delta^{13} \mathrm{C}_{18: 0}$ increased until 26.7 and $27.1 \mathrm{ka}$, respectively (Unit I). Unit I showed highly variable fatty acid $\delta^{13} \mathrm{C}$. Minima in $\delta^{13} \mathrm{C}_{14: 0}$ and $\delta^{13} \mathrm{C}_{18: 0}$ were recorded at $26.7 \mathrm{ka}$ and subsequently in $\delta^{13} \mathrm{C}_{16: 0}$ and $\delta^{13} \mathrm{C}_{18: 1}$ at $26.2 \mathrm{ka}$. All fatty acid $\delta^{13} \mathrm{C}$ increased to $25.4 \mathrm{ka}$ and showed a slight decrease at the top of the sample $(25.0 \mathrm{ka})$. The relationships between the four fatty acid $\delta^{13} \mathrm{C}$ changed through time: from $29.4-28.4 \mathrm{ka}$ there was a close relationship between $\delta^{13} \mathrm{C}_{14: 0}$ and $\delta^{13} \mathrm{C}_{16: 0}$. In

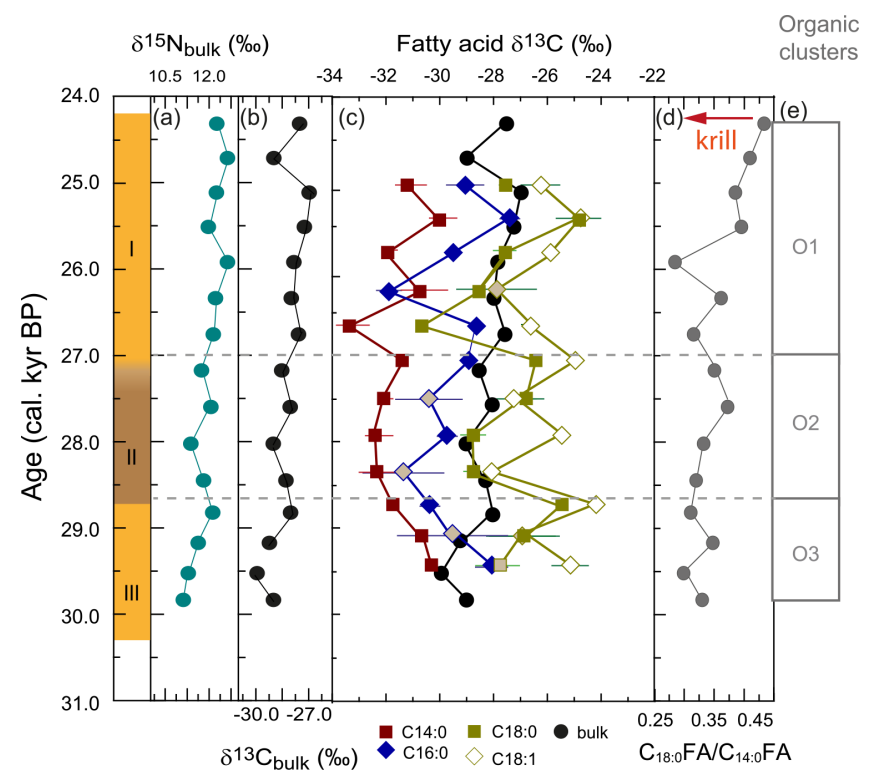

Figure 5. Stable isotope ratios in organic matter from stomach-oil deposit WMM7. The age model uses Holocene "no sea ice" $\Delta R$ (Table 1). (a) Bulk $\delta^{15} \mathrm{~N}$; (b) bulk $\delta^{13} \mathrm{C}$; (c) fatty acid $\delta^{13} \mathrm{C}$ and bulk $\delta^{13} \mathrm{C}$. The standard deviations of replicates are shown: where no error bar is visible the standard variation is smaller than the width of the symbol. Grey shaded data points are those for which the standard variation of the repeat measurements indicated poor reproducibility $\left(>1 \%\right.$ ) . (d) $\mathrm{C}_{18: 0} / \mathrm{C}_{14: 0}$ fatty acid ratio as an indication of relative krill contribution, from Fig. 4; (e) cluster boundaries from Fig. 4.

contrast, from 28.4 ka the $\delta^{13} \mathrm{C}_{14: 0}$ correlated with $\delta^{13} \mathrm{C}_{18: 0}$, and $\delta^{13} \mathrm{C}_{16: 0}$ correlated with $\delta^{13} \mathrm{C}_{18: 1}$.

Cluster analysis on the lipids, pigments, and stable isotope data identified three zones (Figs. 4j, A3). The lower zones aligned with Units III and II, but the upper zone boundary 
occurred at $\sim 27.0 \mathrm{ka}$, slightly above the Unit II-I and XRF zone boundaries and likely driven by the sustained maxima in P410 (Fig. 4h).

\section{Discussion}

Stomach-oil deposit WMM7 is characterized by biochemical variability, which can be attributed to changing biogenic composition through time. In this section, we first evaluate the likely sources of this variation, infer changes in snow petrel diet through time, and investigate how the sea-ice environment may have varied. By doing this we aim to provide greater insight into both the biochemistry of the stomach-oil deposit and critically evaluate its use as a palaeoenvironmental archive.

\subsection{Contributions to stomach-oil biochemistry}

The stomach oil regurgitated by snow petrels at nesting sites provides an integrated archive of diet during the most recent foraging trip in the summer breeding season. These trips may be for several days (Barbraud et al., 1999). During this time, the snow petrel concentrates the lipid components of their prey into stomach oil; this provides an energyrich food source for their chicks (Warham, 1977; Watts and Warham, 1976) and can be spat in defence against predators or against other snow petrels in disputes over access to suitable crevices for nesting. Unlike muscle, feather, or adipose tissues, which involve biosynthesis (e.g. Rau et al., 1992), the basic biochemical composition of the prey is not altered during stomach-oil formation (Watts and Warham, 1976). Thus, the stomach-oil deposits provide a window into the biochemistry of the prey consumed by snow petrels in open waters at the margins of, or within, the sea-ice zone.

We have considered non-diet influences on the stomach-oil deposit geochemistry. A contribution of snow petrel guano to stomach-oil deposits has been indicated previously (Berg et al., 2019; Hiller et al., 1988). However, WMM7 does not show the negative relationship between $\mathrm{C} / \mathrm{N}$ and other elements $(\mathrm{Cl}, \mathrm{P}, \mathrm{S})$ which would have been expected if there was a strong residual signature of guano contributions to the deposits (Berg et al., 2019). The $\mathrm{C} / \mathrm{N}$ ratios are consistent with particulate organic carbon $(\sim 10)$ in modern sea ice (Henley et al., 2012) and fish collected in the Weddell and Lazarev seas ( 3-11) (Rau et al., 1992; Friedrich and Hagen, 1994). We suggest that any contribution of guano to WMM7 is lower than for other published sequences derived from DML stomach-oil deposits (Berg et al., 2019), perhaps due to local topography (including aspect and microclimate), the distance from the nest that the sample was taken, or the history of occupation.

We did not observe formation of K- and C-bearing phosphates by weathering (Berg et al., 2019); rather, the highest $\mathrm{P}$ counts were recorded in Unit II where Ca counts were lower and there was no change in K (Fig. A1). Progressive oxidation of organic matter was not evident: no systematic trends in labile pigment abundances (Fig. $4 \mathrm{~h}$ ) or fatty acid $\delta^{13} \mathrm{C}$ were observed (Fig. 5). Furthermore, bulk $\delta^{13} \mathrm{C}$ values are negatively correlated with $\mathrm{C} / \mathrm{N}$, as observed today in Antarctic fish (and other predators), reflecting the variable contributions of ${ }^{13} \mathrm{C}$-depleted and low-N lipids to the bulk signal (Rau et al., 1992; Friedrich and Hagen, 1994; Cherel et al., 2011). Again, this difference in weathering signal between deposits may reflect local factors at the nesting sites (discussed above).

As observed in other glacial-stage stomach-oil deposits (Berg et al., 2019), WMM7 differs from some modern snow petrel stomach oils (e.g. Warham et al., 1976) by substantially lower contributions of $\mathrm{C}_{18: 1}$ relative to $\mathrm{C}_{16: 0}$ and $\mathrm{C}_{14: 0}$. The lower contributions of polyunsaturated $(<1 \%)$ and monounsaturated fatty acids (e.g. $\mathrm{C}_{18: 1} 9 \pm 2 \%, \mathrm{C}_{16: 1}$ $2.6 \pm 0.3 \%$ ) than in fresh stomach oil of other procellariiform seabirds (Connan et al., 2007) including snow petrels (Warham et al., 1976; Watts and Warham, 1976) could indicate post-depositional oxidation (Berg et al., 2019). However, fatty acid contributions similar to WMM7 have been recorded in a late Holocene DML stomach-oil deposit (Aiello et al., 2011), in prey of snow petrels (Cripps et al., 1999), and in stomach oils from other Procellariiformes (Wang et al., 2007). As previously noted (Berg et al., 2019), the samples of fresh stomach oils (Warham et al., 1976; Watts and Warham, 1976) were from snow petrels foraging in the Ross Sea, where prey availability, and hence stomach-oil biochemistry, may also be different. We therefore suggest that the fatty acid signatures in WMM7 primarily signal a dietary intake rather than variable preservation.

Analyses of stomach contents and observations at sea indicate that snow petrel diet is dominated by fish (12\%-95\%) and krill (35\%-71\%) (e.g. Ridoux and Offredo, 1989; Ainley et al., 1984; Falla, 1937; Fijn et al., 2012), including the Antarctic silverfish Pleuragramma antarctica (family: Nototheniidae) and Antarctic lanternfish Electrona antarctica (family: Myctophidae) (Ainley et al., 2006, 1984). Variable contributions from squid have also been recorded (Ridoux and Offredo, 1989; Ainley et al., 1984; Bierman and Voous, 1950). The dominant fatty acids in WMM7 are consistent with the main snow petrel prey (Table 3): Antarctic krill ( $E u$ phausia superba, high abundances of $\mathrm{C}_{14: 0}, \mathrm{C}_{16: 0}$, sometimes $\mathrm{C}_{18: 1}$; Cripps et al., 1999; Raclot et al., 1998), squid (dominated by $\mathrm{C}_{16: 0}$, plus longer-chain fatty acids $\mathrm{C}_{20: 5}$ and $\mathrm{C}_{22: 6}$; Raclot et al., 1998), and both notothenoid and myctophid fish (high concentrations of $\mathrm{C}_{18: 1(n-9)}, \mathrm{C}_{16: 0}$, and several monounsaturated and polyunsaturated $\mathrm{C}_{20}$ and $\mathrm{C}_{22}$ fatty acids; Imber, 1976; Raclot et al., 1998; Mayzaud et al., 2011). Although only recorded as a minor $(\sim 2 \%)$ contributor to snow petrel diet (Ridoux and Offredo, 1989), in coastal waters ice krill (Euphausia crystallorophias) is found in very high densities (La et al., 2015), characterized by high abundances of the $\mathrm{C}_{18: 1 \omega 9}$ and $\mathrm{C}_{16: 0}$ fatty acids as well as $\mathrm{C}_{14: 0}$ and $\mathrm{C}_{16: 0}$ alcohols (Ju and Harvey, 2004; Bottino, 
1975). The $C_{16: 0}$ fatty acid thus has a mixed origin from krill, fish, and squid in contrast to $\mathrm{C}_{14: 0}$ (Antarctic krill) and $\mathrm{C}_{18: x}$ (fish, ice krill). The offsets in $\delta^{13} \mathrm{C}$ for $\mathrm{C}_{14: 0}, \mathrm{C}_{16: 0}$ and $\mathrm{C}_{18: x}$ (and their different trends through time) confirm that they have different sources in WMM7 (Fig. 5). The offsets between individual fatty acids exceeds the $\sim 1 \%$ enrichment which might be expected through an increase in trophic level (Post, 2002), suggesting an alternative control through temporal or spatial variations in foraging habitat of the snow petrels and/or their prey (Sect. 4.3).

Our interpretation of $\mathrm{C}_{14: 0}$ as an indicator of Antarctic krill inputs to snow petrel diet is broadly supported by elevated $\mathrm{Cu}$ (measured as $\mathrm{Cu} / \mathrm{Ti}$ ) (Rainbow, 1989; Palmer Locarnini and Presley, 1995; Liu et al., 2013) when $\mathrm{C}_{14: 0}$ is also relatively high (by $\mathrm{C}_{16: 0} / \mathrm{C}_{14: 0}$ and $\mathrm{C}_{18: 0} / \mathrm{C}_{14: 0}$ ) (Fig. 4). Thus, we identify two independent measures of the relative contributions of krill which can be applied to WMM7 to investigate broad-scale changes in snow petrel diet through time.

\subsection{Snow petrel diet 30.3-24.3 ka}

The variations in biogenic contributions to stomach-oil deposit WMM7 reveal changing snow petrel diet at decadal (XRF data), centennial, and millennial timescales for the early part of Marine Isotope Stage (MIS) 2, which includes the start of the LGM (30.3-24.3 ka). We note that although each stomach-oil regurgitation provides a snapshot of snow petrel diet during the summer breeding season (November to February), prey biochemistry (and thus stomach-oil composition) may also provide information over varying timescales, reflecting life cycle and tissue turnover rates of the fish, krill and squid consumed by the snow petrel.

Our multi-proxy analysis confirmed that three zones could be identified. Between 30.3 and $28.7 \mathrm{ka}(\sim$ Unit III) elevated $\mathrm{Cu} / \mathrm{Ti}$ and $\mathrm{C}_{14: 0}$ contributions (low $\mathrm{C}_{16: 0} / \mathrm{C}_{14: 0}$ and $\left.\mathrm{C}_{18: 0} / \mathrm{C}_{14: 0}\right)$ identified Antarctic krill as an important component of snow petrel diet, but likely decreasing through time. Although offset by $\sim 2.0 \%$, supporting different sources, both $\delta^{13} \mathrm{C}_{14: 0}$ and $\delta^{13} \mathrm{C}_{16: 0}$ decreased across this time interval, suggesting either a common environmental (prey habitat) signal or that Antarctic krill contributed to both $\mathrm{C}_{14: 0}$ and $\mathrm{C}_{16: 0}$. In contrast, the much higher (and increasing) $\delta^{13} \mathrm{C}_{18: 0}$ and $\delta^{13} \mathrm{C}_{18: 1}$ confirmed a different prey source and/or habitat signal contributing to the $\mathrm{C}_{18}$ fatty acids. Thus, the prey other than Antarctic krill, which were most likely to be fish, occupied a different foraging habitat (see Sect. 4.3).

At $28.7 \mathrm{ka}$ (Unit II) there was a shift in the dominant contributions to the snow petrel stomach oils. Low $\mathrm{Cu} / \mathrm{Ti}$ indicate a prolonged $(\sim 1100$ years) interval wherein Antarctic krill was not a major component of snow petrel diet (Figs. 3, 4), supported by increasing $C_{16: 0} / C_{14: 0}$ and $C_{18: 0} / C_{14: 0}$. Reduced minerogenic inputs (Fig. 3f) and increased marine organic matter (Fig. 4h, i) characterize Unit II: low PC1, elevated $\mathrm{S}, \mathrm{Br}$ (e.g. Leri et al., 2010), chlorins, and $\mathrm{C}_{18: 1}$ (Jónas- dóttir, 2019; Cripps et al., 1999). Although this biochemical signature suggests a dominant phytoplankton fingerprint in snow petrel diet between 28.5 and $27.2 \mathrm{ka}$, phytoplankton are too small to be consumed directly by seabirds. The elevated chlorins (Fig. 4h) seem more likely to indicate that the snow petrels consumed prey with a phytoplankton-dominated diet. Decreasing $\delta^{15} \mathrm{~N}_{\text {bulk }}$ in Unit II may also reflect a shorter food chain, although the shift is small $(<1 \%$, Fig. 5). Preservation of intact phytoplankton in stomach oils is also feasible through secondary ingestion (i.e. in the stomachs of snow petrel prey), since undigested algal cells have been reported in penguin guano (Mychra and Tatur, 1991) and diatoms have been isolated in $P$. antarctica larvae (Vallet et al., 2011) and other stomach-oil deposits (Berg et al., 2019).

The similarity in the trends between $\delta^{13} \mathrm{C}_{16: 0}$ and $\delta^{13} \mathrm{C}_{18: 1}$ (Fig. 5c) confirms an increased importance of prey with $\mathrm{C}_{18}$ fatty acids in their tissues between 28.7 and $27.2 \mathrm{ka}$, consistent with incorporation of a phytoplankton signal in predator tissues, through their consumption of copepods, squid, or fish, which can occur with minimal alteration (e.g. Lee et al., 1971). Elevated ( 20\%) $\mathrm{C}_{18: 1}$ through Units I and II supports an increased contribution of fish to the snow petrel diet between 28.7 and $27.4 \mathrm{ka}$, but identifying the particular fish species is more challenging. Both $P$. antarctica (Mayzaud et al., 2011) and several species of myctophid fish including E. antarctica (Imber, 1976; Raclot et al., 1998) contain $\mathrm{C}_{18: 1}$, and their $\delta^{13} \mathrm{C}$ and $\delta^{15} \mathrm{~N}$ values suggest that $P$. antarctica and $E$. antarctica have overlapping trophic niches (Rau et al., 1992). High abundances of $\mathrm{C}_{16: 0}$ in myctophids (Mayzaud et al., 2011) may account for the similarity in $\delta^{13} \mathrm{C}_{16: 0}$ and $\delta^{13} \mathrm{C}_{18: 1}$ in Unit II. Although the main myctophid prey today are euphausiids (including krill; Saunders et al., 2019), this diet is not consistent with the low $\mathrm{Cu} / \mathrm{Ti}$ and low $\mathrm{C}_{14: 0}$ contributions to WMM7 in Unit II, nor with the $>4 \%$ offset between $\delta^{13} \mathrm{C}_{14: 0}$ and $\delta^{13} \mathrm{C}_{18: 1}$. Alternatively, an increased contribution from nototheniid fish (e.g. $P$. antarctica), the diet of which includes copepods as well as krill, might explain the apparently elevated phytoplankton signature and the reduced contribution of Antarctic krill to snow petrel diet throughout Unit II.

From 27.4-25.9 ka (lower Unit I), Antarctic krill returned as an important component (high $\mathrm{Cu} / \mathrm{Ti}$, higher $\mathrm{C}_{14: 0}$ contributions), although the positive relationship between $\delta^{13} \mathrm{C}_{16: 0}$ and $\delta^{13} \mathrm{C}_{18: 1}$ suggests that fish was also important in the diet. Reduced input of marine organic matter was apparent in Br, S, and chlorins (Figs. 3 and 4). Fatty acid $\delta^{13} \mathrm{C}$ showed higher variability than in Units II and IIII. From $25.2 \mathrm{ka}$ to the top of the deposit (24.3 ka; Upper Unit I), increasing minerogenic contributions may explain the simultaneous decrease in $\mathrm{Cu} / \mathrm{Ti}, \mathrm{Br} / \mathrm{Ti}$, and $\mathrm{S} / \mathrm{Ti}$, which contrasts with the anti-phase behaviour between $\mathrm{Cu}$ and $\mathrm{Br}$ or $\mathrm{S}$ discussed previously, and the $\mathrm{Cu} / \mathrm{Ti}$ minima, whilst $\mathrm{C}_{14: 0}$ inputs increase slightly. Fatty acid $\delta^{13} \mathrm{C}$ values also show concomitant peaks and lows from 25.5-25.0 ka, suggesting there 
may be a strong baseline (i.e. primary producer) control over the stable isotope values.

We note that the changes in relative contributions of Antarctic krill and fish in the diet that we inferred for WMM7 are not reflected in the range of $\delta^{15} \mathrm{~N}_{\text {bulk }}(\sim 1.2 \%$ o), which lies below modern trophic-level offsets of $>2 \%$ o (e.g. Seyboth et al., 2018) including some krill-fish offsets of $~ 5 \%$ $7 \%$ in the Southern Ocean (e.g. Polito et al., 2011), and suggest minimal changes to snow petrel trophic level between 30.3 and $24.3 \mathrm{ka}$. However, $\delta^{15} \mathrm{~N}_{\text {bulk }}$ reflects $\delta^{15} \mathrm{~N}$ in prey tissues, which can themselves vary over space and time (Quillfeldt and Masello, 2020) so that trophic values can only be calculated if baseline (primary producer) $\delta^{15} \mathrm{~N}$ is known (Post, 2002). Since baseline $\delta^{15} \mathrm{~N}$ is poorly constrained for our interval of study and since snow petrel prey integrate $\delta^{15} \mathrm{~N}$ across different temporal and spatial scales, it seems likely that the small range of $\delta^{15} \mathrm{~N}_{\text {bulk }}$ in WMM7 reflects either baseline $\delta^{15} \mathrm{~N}_{\text {bulk }}$ or mixing of multiple signals over time, which we are unable to disentangle with our analyses.

In summary, the stomach-oil deposit WMM7 indicates several changes to snow petrel diet between 30.3 and $24.3 \mathrm{ka}$. Antarctic krill and fish provided important contributions between 30.3-28.7 ka (Unit III) and 27.4-24.3 ka (Unit I). Between 28.7 and $27.4 \mathrm{ka}$ (Unit II) a prolonged interval of low Antarctic krill contributions suggests a shift towards a more fish-dominated diet. The strong phytoplankton fingerprint during this time also suggests that the fish themselves had a reduced krill contribution to their diet, highlighting a substantial change to the food chain in the foraging habitat of the snow petrels. In the following section, we consider the likely palaeoenvironmental drivers and implications of these signals.

\subsection{Evolution of sea-ice environments (30.3-24.3 ka)}

Seabird diets vary over time and space, depending on the availability of prey species, in turn reflecting environmental conditions within their foraging range (Mills et al., 2020, 2021). For example, it has been proposed that myctophid fish become more important to seabird diet when krill availability is low, during winter when sea ice is more extensive, and/or in response to temporal and spatial changes in summer production (Nicol, 2006; Watanuki and Thiebot, 2018). Prey biochemistry may also reveal environmental information: $\delta^{13} \mathrm{C}$ decreases with increasing latitude (Francois et al., 1993; Trull and Armand, 2001) or between coastal and offshore waters (Trull and Armand, 2001), whereas $\delta^{13} \mathrm{C}$ increases within the sea ice during spring melt (Dunbar and Leventer, 1992). These differences are reflected in the $\delta^{13} \mathrm{C}$ of crustaceans, fish, and squid in these habitats and in turn in their predators including seabirds (Cherel et al., 2011; Jaeger and Cherel, 2011; Delord et al., 2016; Phillips et al., 2009).

The presence of multiple stomach-oil deposits in DML during MIS 3 and the early LGM (Berg et al., 2019) confirms that there must have been accessible prey within range of the breeding snow petrels at the Untersee during the spring and summer. WMM7 has a very stable accumulation rate (Fig. 2), and we found no evidence for hiatuses, suggesting that the site was not affected by long periods of nestsite abandonment related to unfavourable climatic conditions (e.g. snow cover over the site, perennial sea ice preventing access to prey within foraging range) or local factors (e.g. burial by rock) (Olivier and Wotherspoon, 2006; Olivier et al., 2005). We consider it unlikely that the snow petrels were foraging at an oscillating spring-summer sea-ice margin because WMM7 deposition coincides with an expanding then maximum summer sea-ice extent in the Atlantic sector of the Southern Ocean between 29 and 22 ka (Fig. 6) (Collins et al., 2012; Gersonde et al., 2005, 2003; Allen et al., 2011; Fischer et al., 2007; Xiao et al., 2016; Goto-Azuma et al., 2019), which places the summer sea-ice margin at $55-60^{\circ} \mathrm{S}$, $>1500-2000 \mathrm{~km}$ away from WMM7 and far beyond the typical maximum foraging range for this species (Fig. 1).

Today, snow petrel foraging in high $(>80 \%)$ sea-ice concentrations occurs in the margins of polynyas (Ainley et al., 1984), which are regions of open water within the winter or multiyear sea-ice pack critical for enabling high levels of primary productivity, carbon cycling, and air-sea gas exchange (Arrigo et al., 2008; Sherrell et al., 2015). Several marine sites in the Weddell and Lazarev seas have indicated sporadic polynya formation during MIS 2 and 3 (Fig. 1) (Sprenk et al., 2014; Smith et al., 2010; Thatje et al., 2008; Weber et al., 1994). Deposit WMM7 confirms previous proposals that polynyas were important for supporting snow petrel colonies through the last glacial (Thatje et al., 2008; Berg et al., 2019). We interpret our new records of changes in snow petrel diet in MIS 2 to have occurred as a result of changes to conditions within, and/or the locations of, polynyas offshore of DML. Unlike today, when polynyas are largely winter-spring phenomena which impact spring-summer productivity during or after sea-ice melt as "post-polynyas" (Arrigo and van Dijken, 2003), summer sea surface temperatures below freezing in the Weddell Sea (Gersonde et al., 2005) would have supported more extensive sea-ice (and polynya) formation in summer during the last glacial stage (Fischer et al., 2007).

Diet studies indicate that snow petrels consume a mixed diet of krill, squid, and myctophid fish when feeding beyond the continental shelf, whereas fish are most important in shelf waters, at least in the Ross Sea (e.g. Ainley et al., 1992; Fijn et al., 2012; Ridoux and Offredo, 1989; Ainley et al., 1984; Falla, 1937). A similar pattern in Antarctic petrels (Thalassoica antarctica) has been attributed to a lack of Antarctic krill inshore during the breeding season (Nicol, 1993). Although adult krill and larvae over-winter within the sea ice, post-larval Antarctic krill are mostly oceanic (Atkinson et al., 2008). During the austral spring and summer, corresponding to the breeding season of the snow petrels, adult Antarctic krill move to deeper waters for egg development (Nicol, 2006), which may account for the observed increase in krill in snow petrel diets when they forage beyond the continental 


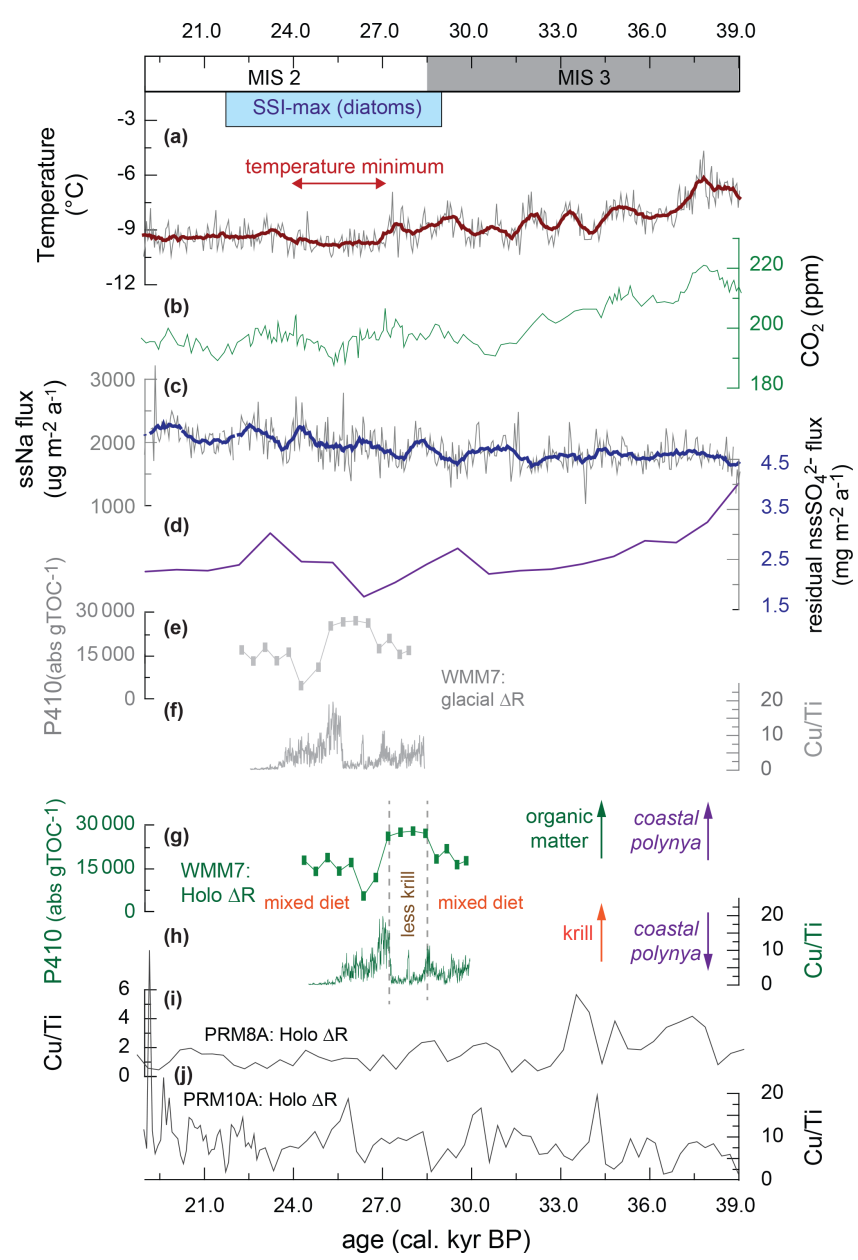

Figure 6. Variations in snow petrel diet across the MIS 3-2 transition, including the interval of maximum summer sea-ice extent (SSI-max) in the Scotia Sea from Allen et al. (2011) and plotted in Fig. 1. (a) Air temperature recorded by $\delta D$ in an EPICA-DML ice core (Jouzel et al., 2007); (b) atmospheric $\mathrm{CO}_{2}$ from a West Antarctic Ice Sheet (WAIS) ice core (Bauska et al., 2021); (c) seasalt Na flux from an EPICA-DML ice core (Fischer et al., 2007); (d) biogenic sulfate flux to the EPICA-DML ice core, generated by correcting for terrestrial contributions to non-sea-salt $\mathrm{Na}$ flux (Goto-Azuma et al., 2019); (e) WMM7 chlorin pigment abundance plotted using the glacial-stage (enhanced sea ice) $\Delta R$ from Table 1 ; (f) WMM7 $\mathrm{Cu} / \mathrm{Ti}$ ratio plotted using the glacial-stage (enhanced sea ice) $\Delta R$ from Table 1.; (g) WMM7 chlorin pigment abundance plotted using the Holocene (low or absent sea ice) $\Delta R$ from Table 1, as shown in Fig. 4; (h) WMM7 Cu / Ti ratios plotted using the Holocene (low or absent sea ice) $\Delta R$ from Table 1 , as shown in Fig. 3. As discussed in the text, we prefer to apply the Holocene $\Delta R$ calibrations of $(\mathbf{g}, \mathbf{h})$ and interpret high chlorin values $(\mathbf{g})$ as indicative of an enhanced phytoplankton and/or reduced krill signal, whereas high $\mathrm{Cu} / \mathrm{Ti}$ ratios (h) are interpreted as evidence of enhanced krill inputs. As discussed in the text, we infer the loss of krill from the snow petrel diet at $\sim 27-28 \mathrm{ka}$ to represent polynyas opening over the continental shelf. (i, j) $\mathrm{Cu} / \mathrm{Ti}$ signals in other DML stomach-oil deposits from analysis in Berg et al. (2019) recalibrated using the Holocene $\Delta R$ from Table 1 . shelf. Given the importance of deep waters for the Antarctic krill life cycle, we infer that the mixed diet of krill and fish in Units I and III represents snow petrels foraging in polynyas located beyond the continental shelf. In contrast, the observed shift in fatty acid and element profiles in Unit II suggests that fish became more important to snow petrel diet, suggesting that polynyas had opened up over the continental shelf between 28.7 and $27.4 \mathrm{ka}$. We hypothesize that these shifts in foraging habitat reflect changes in sea-ice conditions by influencing either prey distributions or access to surface waters for feeding.

We discount a latitudinal control over $\delta^{13} \mathrm{C}$ in WMM7 because the seasonal and spatial ranges of $\delta^{13} \mathrm{C}$ within sea ice can exceed the Southern Ocean latitudinal $\delta^{13} \mathrm{C}$ gradient (Dunbar and Leventer, 1992; Kennedy et al., 2002) due to changing $\mathrm{CO}_{2(\mathrm{aq})}$ supply and productivity (Henley et al., 2012; Kennedy et al., 2002). Organic matter in the sea-ice zone tends to have elevated $\delta^{13} \mathrm{C}$ compared to open waters beyond the ice edge (Henley et al., 2012; Kennedy et al., 2002 ), but $\delta^{13} \mathrm{C}_{14: 0}$ production in open waters for WMM7 is not consistent with the expanded sea-ice extent of MIS 3-2 outlined above. Rather, low $\delta^{13} \mathrm{C}_{14: 0}$ is consistent with (krill) production in the winter-spring sea ice (Dunbar and Leventer, 1992; Henley et al., 2012) and/or more oceanic (rather than coastal) habitats (Cherel et al., 2011), with ${ }^{13}$ C-enriched $\mathrm{C}_{18}$ fatty acids in WMM7 reflecting primary production and fish tissues from summer and/or more coastal habitats. No long-term trends are recorded in $\delta^{13} \mathrm{C}_{18: 0}$ or $\delta^{13} \mathrm{C}_{18: 1}$, and all four of the major fatty acids have highly variable $\delta^{13} \mathrm{C}$ (ranges $>2 \%$ ) after $27.0 \mathrm{ka}$ (Unit I). In contrast, a long-term decrease in $\delta^{13} \mathrm{C}_{14: 0}$ between 29.4 and $28.4 \mathrm{ka}$ (Units III and II) occurs alongside declining Antarctic krill contributions $\left(\mathrm{Cu} / \mathrm{Ti}\right.$ and $\left.\mathrm{C}_{18: 0} / \mathrm{C}_{14: 0}\right)$. The cause of the long-term decline in $\delta^{13} \mathrm{C}_{14: 0}$ is unclear but could reflect prolonged winter (low $\delta^{13} \mathrm{C}$ ) sea ice, which leads to ${ }^{13} \mathrm{C}$ depletion (Dunbar and Leventer, 1992) and also to restricted access to krill (Watanabe et al., 2020), even though increased winter sea ice is important for Antarctic krill recruitment (Atkinson et al., 2004; Jaeger and Cherel, 2011). Alternatively, declining $\delta^{13} \mathrm{C}_{14: 0}$ could reflect enhanced upwelling of $\mathrm{CO}_{2(\mathrm{aq})}{ }^{-}$ rich but low- $\delta^{13} \mathrm{C}$ circumpolar deep water (Bostock et al., 2004; Menviel et al., 2015) during the season of Antarctic krill production. The decreasing $\delta^{13} \mathrm{C}_{14: 0}$ and krill contributions from $30.3 \mathrm{ka}$ culminate in the shift to a diet rich in fish by $28.7 \mathrm{ka}$ (Unit II), which we infer to represent coastal polynya development, reducing krill recruitment in shallower waters and/or reducing snow petrel access to krill with more widespread spring sea ice. Elevated phytoplankton contributions between 28.5 and $27.2 \mathrm{ka}$ in WMM7 are also consistent with the highest primary productivity and/or low grazing observed today in shallow (continental shelf) waters, including coastal polynyas (Delmont et al., 2014; Karnovsky et al., 2007; Arrigo and van Dijken, 2003).

The cause of the millennial-scale switching between foraging in coastal and open-ocean polynyas is not clear but 
could reflect ocean temperatures, wind speeds and directions (Morales Maqueda et al., 2004), and availability of continental shelf waters. Colder Southern Ocean waters during glacial stages (Gersonde et al., 2005) are expected to limit formation of the open-ocean polynyas which rely on ocean-driven sea-ice melt (Ferrari et al., 2014), and reduced vertical mixing may have resulted from sea-ice-driven stratification in the upper water column (Crosta and Shemesh, 2002). However, upwelling driven by wind and/or terraces on the continental slope may explain LGM polynya formation at site PS1506 (Thatje et al., 2008) and upstream of site PS1795 (Sprenk et al., 2014), within the foraging range of snow petrels breeding at the Untersee (Fig. 1). Enhanced wind speeds during glacial stages are also expected to have encouraged sea-ice break-up and coastal (ice-sheet- or ice-shelf-proximal) polynya formation (Morales Maqueda and Rahmstorf, 2002; Sprenk et al., 2014; Smith et al., 2010; Weber et al., 1994), as observed today (Morales Maqueda et al., 2004).

Unlike other parts of the Antarctic ice sheet (Bentley et al., 2014), access of snow petrels to continental shelf waters during MIS 2 may also have been facilitated by relatively minor changes to vertical and lateral ice-sheet extent in DML over the last 100000 years (Hillenbrand et al., 2014; Mackintosh et al., 2014). The exact position of the LGM ice-sheet limit on the DML continental shelf is not well constrained (Fig. 1) (Hillenbrand et al., 2014), but our data from WMM7 suggest that at least part of the continental shelf was free of glacial ice, enabling the development of coastal polynyas within MIS 2. Times of ice-sheet advance may then have reduced the area of available continental shelf and increased winddriven polynya formation over the continental slope, as suggested by Weber et al. (1994) and Sprenk et al. (2014), which would account for the increased contribution of Antarctic krill to snow petrel diet. The relatively restricted extent of the continental shelf at DML $(<100 \mathrm{~km})$ may make coastal polynya formation in this region particularly sensitive to icesheet advance.

The sustained presence of polynyas through MIS 3-2, as recorded in WMM7 and in other DML sequences (Fig. 6) (Berg et al., 2019), may also offer an explanation for the small amplitude of millennial-scale oscillations in sea-salt $\mathrm{Na}$ to the EPICA ice core and the weak relationship with Antarctic temperatures (Fischer et al., 2007). Although we show that polynya properties changed through time (Fig. 6), the open waters within the sea-ice pack would have provided a continuous supply of sea-salt Na to the ice core site. Polynyas may have also affected the strength of the sea iceclimate feedbacks during MIS 2: introducing only $2 \%-8 \%$ open waters into the LGM sea-ice pack (compared to $10 \%-$ $20 \%$ for winter today) reduces the Southern Ocean contribution to the $\mathrm{LGM} \mathrm{CO} 2$ drawdown from $\sim 80 \%$ to $15 \%-$ $50 \%$ via enhanced ocean-atmosphere $\mathrm{CO}_{2}$ transfer (Morales Maqueda and Rahmstorf, 2002). In contrast, increasing brine formation transfers dense water and carbon to the deep ocean (Bouttes et al., 2011) and could have been enhanced by polynya formation (Paillard and Parennin, 2004). Brine formation over the continental shelves or at the ice-sheet margin has been proposed as conducive to formation of dense glacial Antarctic Bottom Water (AABW) and the associated deepocean storage of $\mathrm{CO}_{2}$ (Paillard and Parrenin, 2004; Adkins, 2013; Adkins et al., 2002). It is currently difficult to evaluate the relationship between the proposed variability in polynya positions and the millennial-scale oscillations in atmospheric $\mathrm{CO}_{2}$ (Fig. 6), in part because it is unclear whether the variations in surface ocean productivity observed in the stomachoil deposits are related to changes in the efficiency of the biological pump and $\mathrm{CO}_{2}$ drawdown (e.g. for Unit II with high chlorin inputs). Furthermore, the relative impact of polynyas compared to other Southern Ocean carbon cycle processes is unclear, given that a combination of brine formation related to sea-ice growth, changes in deep-ocean stratification, and iron fertilization of subantarctic waters is invoked to account for the observed $\mathrm{CO}_{2}$ drawdown (e.g. Bouttes et al., 2011; Marzocchi and Jansen, 2019; Sigman et al., 2021). The relative impact of the polynyas between winter and summer seasons during the last glacial stage is also uncertain, since the large changes in sea-ice extent (Fig. 1) will likely also have affected the air-sea gas exchange on seasonal timescales. Our age model uncertainties also limit confident correlation between WMM7 and the ice core $\mathrm{CO}_{2}$ record, so further testing is required to explore whether polynya development along the DML coastline contributed to observed changes in atmospheric $\mathrm{CO}_{2}$.

\section{Conclusions}

Here, we present a multi-proxy analysis of stomach-oil deposits of snow petrels from Dronning Maud Land, Antarctica. We show that variation in trace metals and fatty acid distributions strongly suggests changes in snow petrel diet between 30.3 and $24.3 \mathrm{ka}$. We show that, as today, a mixed diet of Antarctic krill and fish characterizes much of the record. However, between 28.7 and 27.4 cal kyr BP signals of Antarctic krill in the diet almost disappear. By linking dietary signals in the deposits to modern feeding habits and foraging ranges, we highlight the presence of open water (polynyas) within more extensive summer sea-ice cover during MIS 2. The reduced contribution of Antarctic krill to the snow petrel diet between 28.7 and $27.4 \mathrm{ka}$ suggests restriction of polynyas to the continental shelf, limiting krill recruitment or access to waters where krill were present. Our results show that extensive, thick, and multiyear sea ice was not always present close to the continent during MIS 2. These results add to a growing body of evidence which shows that seasonal changes in sea-ice extent and the presence of polynyas were likely important drivers of sea ice-climate feedbacks during glacial stages, whilst also highlighting the potential of stomach-oil deposits as a palaeoenvironmental archive of Southern Ocean conditions. 


\section{Appendix A}
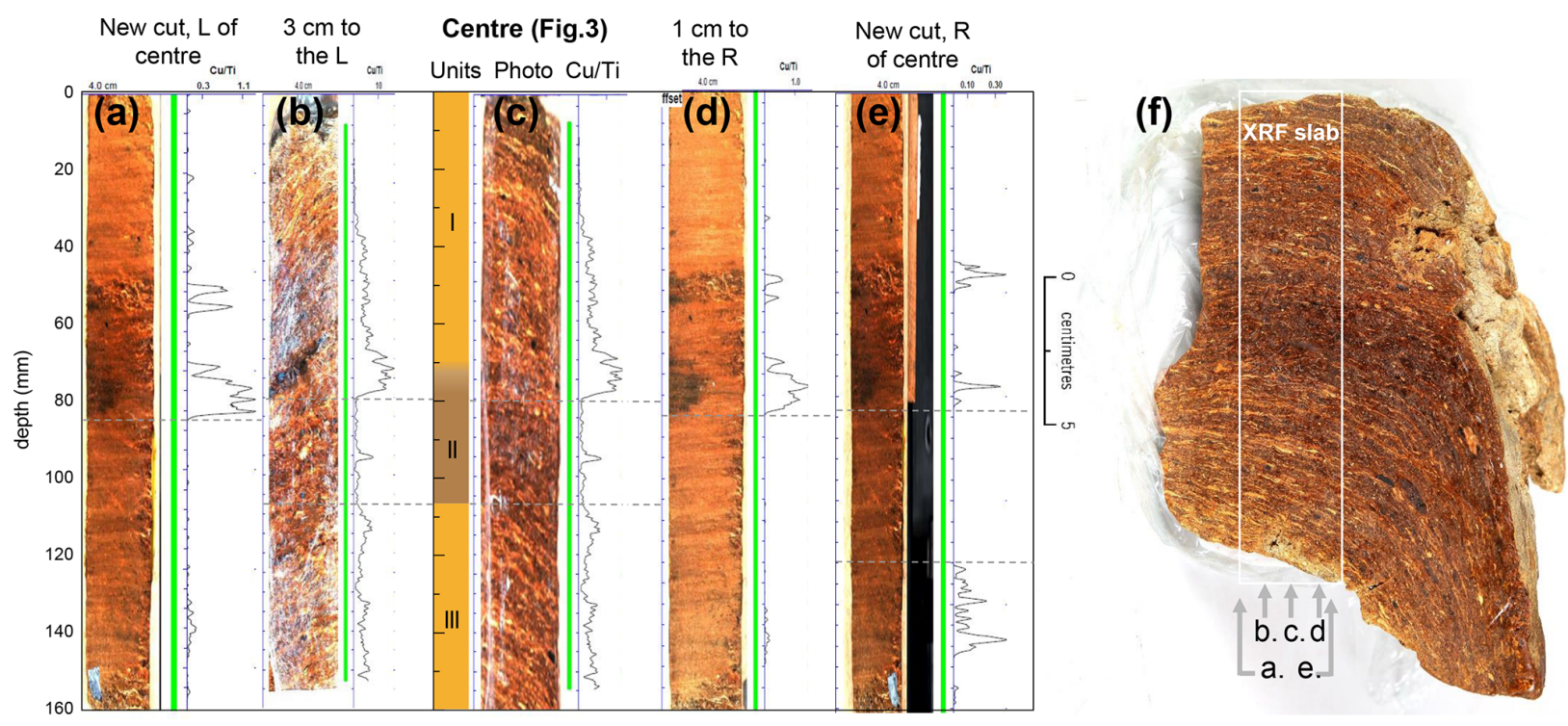

Figure A1. Consistency of XRF scanning signals in deposit WMM7. The XRF data presented in Fig. 3 were recovered from a central slab of WMM7, where we identified the longest sequence of horizontal laminae (Fig. 3). Here we show additional scans to investigate the internal consistency of the signals. Panels (a)-(e) correspond to lines a-e in panel (f). Scans were undertaken to the left (b) and right (d) of the centreline (c), and then two further cuts were used to investigate signals perpendicular to the cut surface (a, e). Away from the central line the signals are less strong and sometimes intermittent, but the laminae also dip sharply away from the centre (f), suggesting more heterogenous accumulation, perhaps due to distance from the nest and/or nest morphology.

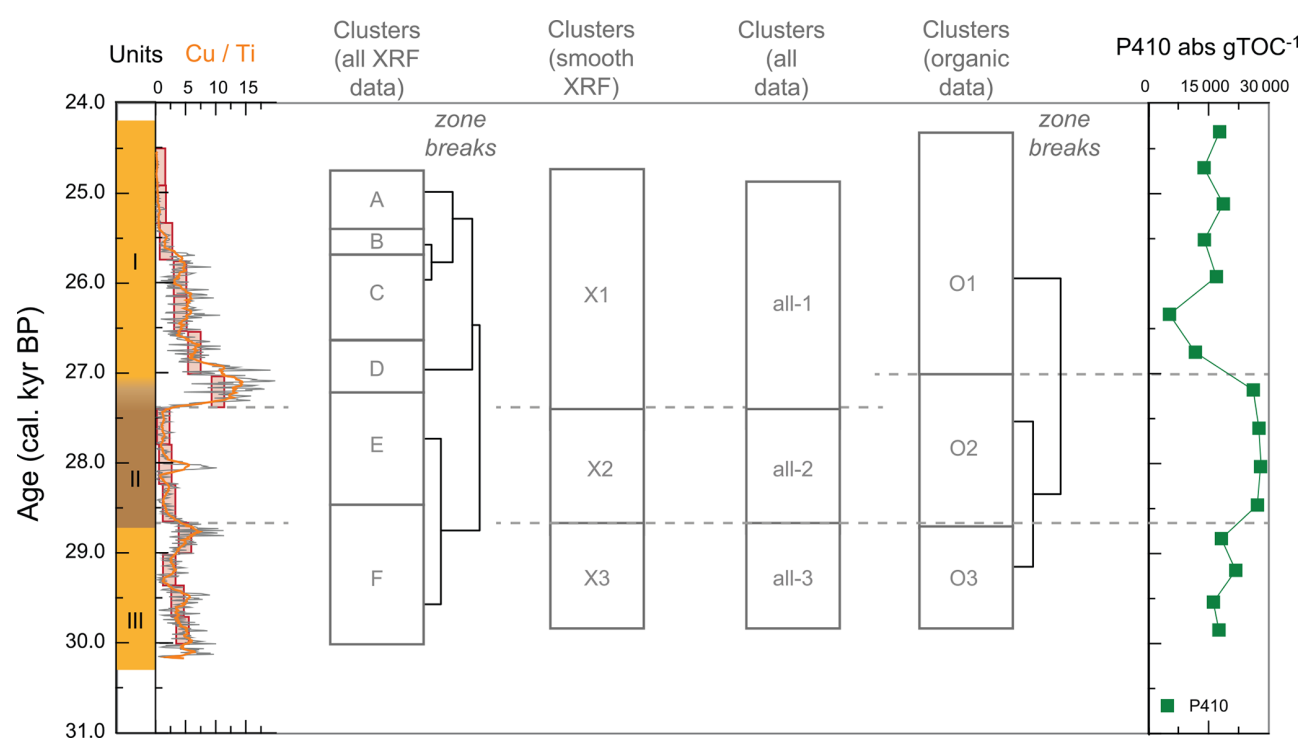

Figure A2. Comparison of cluster analysis results for original XRF data, resampled XRF data (shown in Fig. 3), and organic indicator data (shown in Fig. 4). XRF data between 0-10 and 155-160 mm were removed before analysis. The left panel shows the original Cu / Ti data (grey line) with $\sim 100$-year smoothing (orange line, as in Fig. 3), alongside resampled $\mathrm{Cu} / \mathrm{Ti}$ data (red squares) used for cluster analysis. The right panel shows the $\mathrm{P} 410$ pigment absorbance signal, which may account for the offset in the $\mathrm{O} 1 / \mathrm{O} 2$ cluster boundary compared to $1 / 2$ boundary in other analyses. 


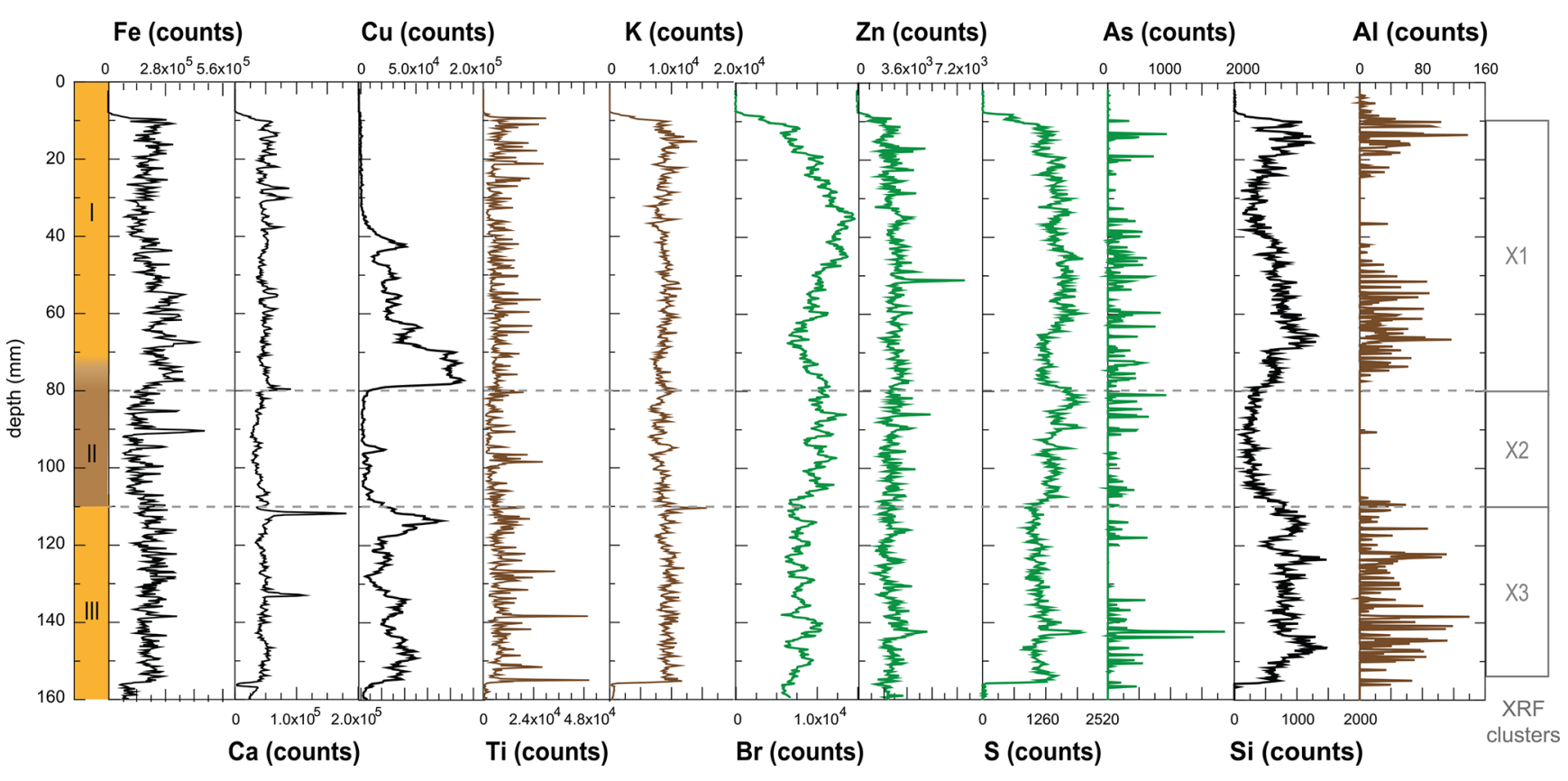

Figure A3. Element contributions to stomach-oil deposit WMM7, recorded by ITRAX XRF scanning (Croudace et al., 2006). Note that the amplitude of the signal decreases from left to right. Potential minerogenic (Ti, K, Al; brown), biogenic (Br, Zn, S, As; green), and mixed (Fe, $\mathrm{Ca}, \mathrm{Cu}, \mathrm{Si}$; black) sources are noted. Cluster analysis was performed after removing data from $0-10$ and $155-160 \mathrm{~mm}$ where several elements record values of zero.

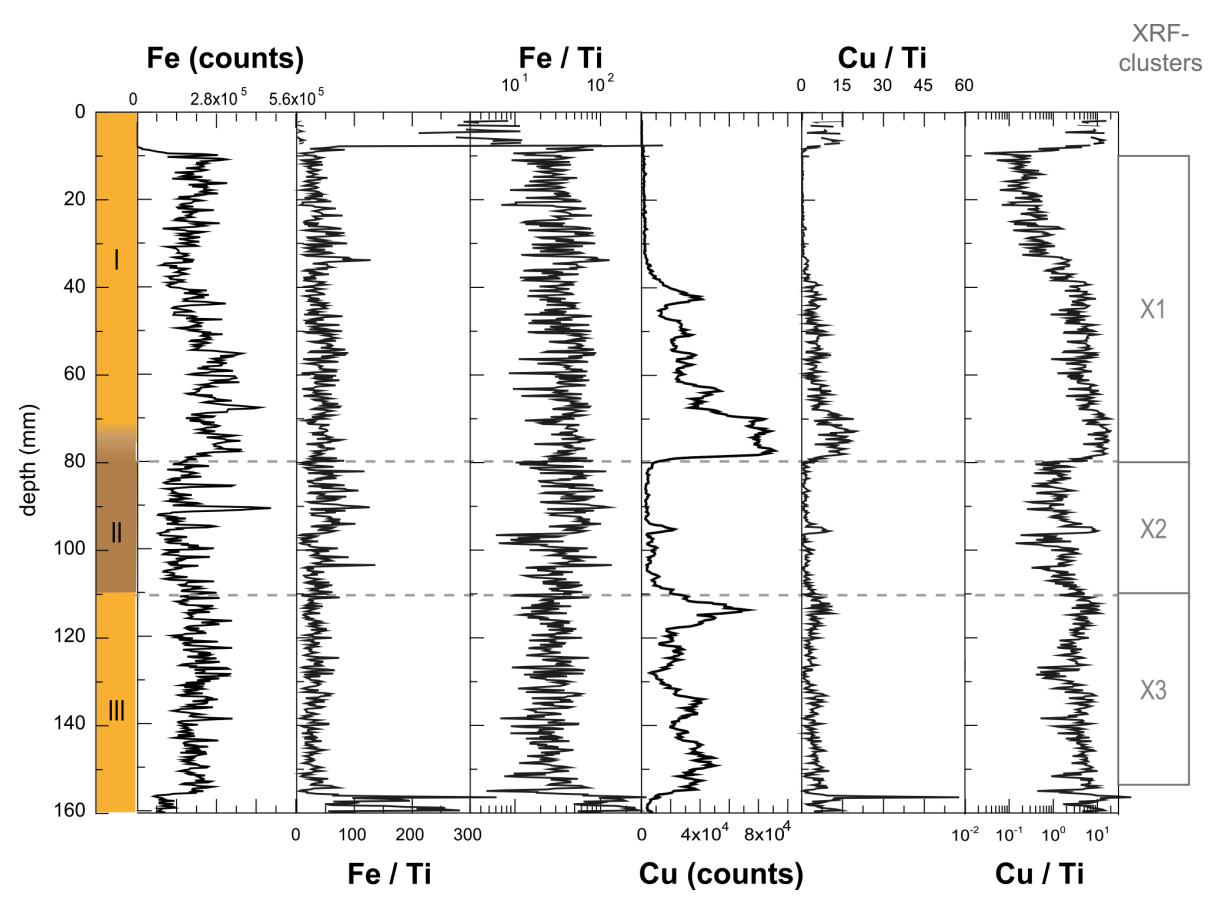

Figure A4. Effect of normalization for minerogenic inputs on the $\mathrm{Fe}$ and $\mathrm{Cu}$ signals in WMM7. Due to low or absent contributions of $\mathrm{Al}$ (Fig. A3), data were normalized to Ti. Fe / Ti and $\mathrm{Cu} / \mathrm{Ti}$ are shown here for comparison as the original ratios and on a log scale. Fig. 3 presents all normalized XRF data on a linear scale, excluding 0-10 and 155-160 mm, where very low counts of one or more element lead to anomalous values. 


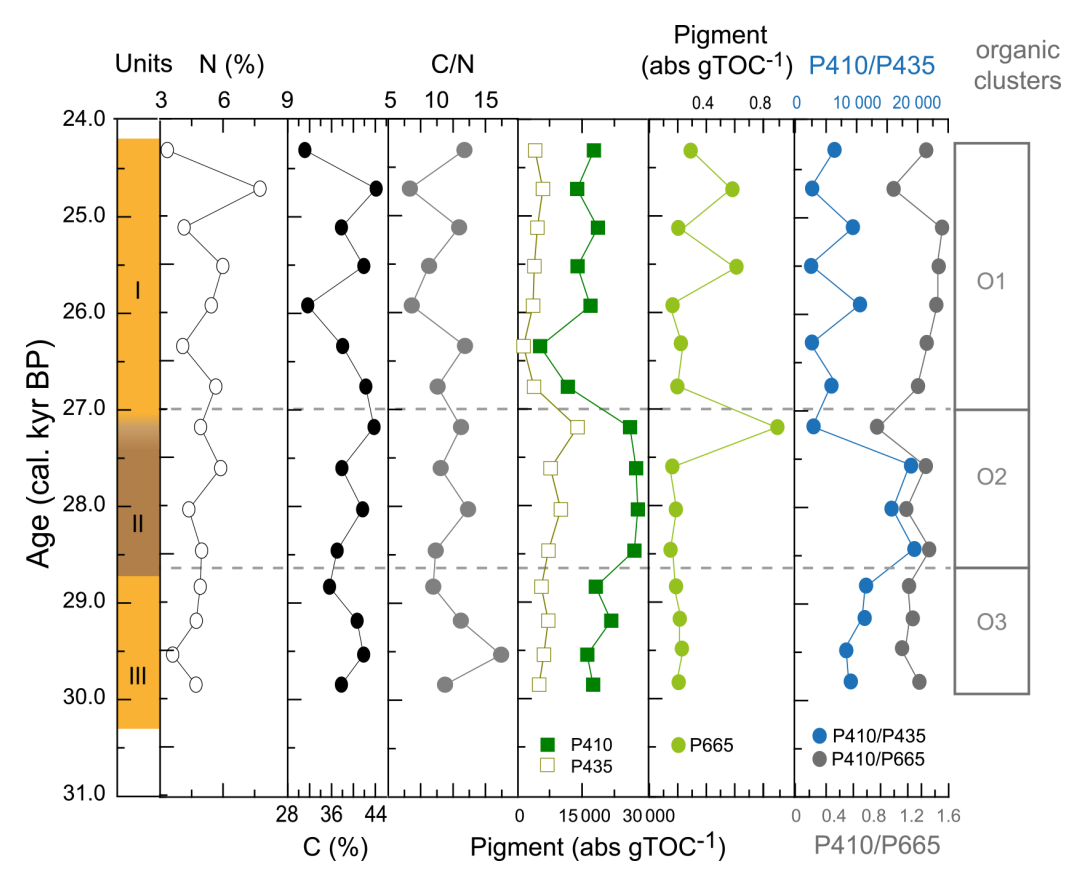

Figure A5. Additional indicators of organic matter composition of WMM7. The $\% \mathrm{~N}$ and $\% \mathrm{TOC}$ were used to generate the $\mathrm{C} / \mathrm{N}$ ratios presented in Fig. 4. The dominant pigments (P410, P435) are shown in comparison to the much lower contribution of P665, which has an exclusive chlorin origin but which is also 3 orders of magnitude lower in abundance than P410.

Data availability. All new proxy data presented here are available at https://doi.org/10.1594/PANGAEA.939211 (McClymont et al., 2021).

Author contributions. ELM, MJB, DAH, and GK designed the study. ELM, CLSJ, MDW, TW, IWC, SB, and DG carried out the laboratory work and data analysis. ELM prepared the initial paper, discussing interpretations and text with MB, DH, MDW, IWC, SB, SSRJ, LS, and RAP. The final paper was edited and reviewed by all authors.

Competing interests. At least one of the (co-)authors is a member of the editorial board of Climate of the Past. The peer-review process was guided by an independent editor, and the authors also have no other competing interests to declare.

Disclaimer. Publisher's note: Copernicus Publications remains neutral with regard to jurisdictional claims in published maps and institutional affiliations.

Special issue statement. This article is part of the special issue "Reconstructing Southern Ocean sea-ice dynamics on glacial-tohistorical timescales". It is not associated with a conference.
Acknowledgements. Our thanks are given to Ulrich Wand and Wolf-Dieter Hermichen for sampling, documentation, and sample storage at the Alfred-Wegener-Institut Helmholtz-Zentrum für Polar- and Meeresforschung research centre in Potsdam. We also thank Amanda Hayton and Kathryn Melvin for laboratory support at Durham University, as well as the three anonymous reviewers who provided constructive feedback to improve the paper.

Financial support. This research has been supported by the European Research Council H2020 (ANTSIE (grant no. 864637)), the Deutsche Forschungsgemeinschaft (SPP 1158 "Antarctic Research with comparative investigations in Arctic ice areas" (grant no. BE4764/5-1)), and the Leverhulme Trust (Philip Leverhulme Prize and Research Leadership Award).

Review statement. This paper was edited by Laurie Menviel and reviewed by three anonymous referees.

\section{References}

Ackley, S. F., Xie, H., and Tichenor, E. A.: Ocean heat flux under Antarctic sea ice in the Bellingshausen and Amundsen Seas: two case studies, Ann. Glaciol., 56, 200-210, 2015.

Adkins, J. F.: The role of deep ocean circulation in setting glacial climates, Paleoceanography, 28, 539-561, https://doi.org/10.1002/palo.20046, 2013. 
Adkins, J. F., McIntyre, K., and Schrag, D. P.: The Salinity, Temperature, and $\delta^{18} \mathrm{O}$ of the Glacial Deep Ocean, Science, 298, 17691773, 2002.

Aiello, A., Fattorusso, E., Menna, M., Vitalone, R., Schröder, H. C., and Müller, W. E. G.: Mumijo traditional medicine: fossil deposits from antarctica (chemical composition and beneficial bioactivity), Evid.-Based Compl. Alt., 2011, 738131-738131, https://doi.org/10.1093/ecam/nen072, 2011.

Ainley, D. G., O'Connor, E. F., and Boekelheide, R. J.: The marine ecology of birds in the Ross Sea, Antarctica, in: American Ornithologist's Union Ornithological Monograph, 97, 1-97, https://doi.org/10.2307/40166773, 1984.

Ainley, D. G., Ribic, C. A., and Fraser, W. R.: Does prey preference affect habitat choice in Antarctic seabirds?, Mar. Ecol. Prog. Ser., 90, 207-221, 1992.

Ainley, D. G., Hobson, K. A., Crosta, X., Rau, G. H., Wassenaar, L. I., and Augustinus, P. C.: Holocene variation in the Antarctic coastal food web: linking $\delta \mathrm{D}$ and $\delta^{13} \mathrm{C}$ in snow petrel diet and marine sediments, Mar. Ecol. Prog. Ser., 306, 31-40, 2006.

Allen, C. S., Pike, J., and Pudsey, C. J.: Last glacial-interglacial sea-ice cover in the SW Atlantic and its potential role in global deglaciation, Quaternary Sci. Rev., 30, 2446-2458, 2011.

Arrigo, K. R. and van Dijken, G. L.: Phytoplankton dynamics within 37 Antarctic coastal polynya systems, J. Geophys. Res.-Oceans, 108, 3271, https://doi.org/10.1029/2002JC001739, 2003.

Arrigo, K. R., van Dijken, G., and Long, M.: Coastal Southern Ocean: A strong anthropogenic $\mathrm{CO}_{2}$ sink, Geophys. Res. Lett., 35, L21602, https://doi.org/10.1029/2008GL035624, 2008.

Atkinson, A., Siegel, V., Pakhomov, E., and Rothery, P.: Long-term decline in krill stock and increase in salps within the Southern Ocean, Nature, 432, 100-103, https://doi.org/10.1038/nature02996, 2004.

Atkinson, A., Siegel, V., Pakhomov, E. A., Rothery, P., Loeb, V., Ross, R. M., Quetin, L. B., Schmidt, K., Fretwell, P., Murphy, E. J., Tarling, G. A., and Fleming, A. H.: Oceanic circumpolar habitats of Antarctic krill, Mar. Ecol. Prog. Ser., 362, 1-23, 2008.

Barbraud, C., Weimerskirch, H., Robertson, G. G., and Jouventin, P.: Size-related life history traits: insights from a study of snow petrels (Pagodroma nivea), J. Anim. Ecol., 68, 1179-1192, https://doi.org/10.1046/j.1365-2656.1999.00361.x, 1999.

Bauska, T. K., Marcott, S. A., and Brook, E. J.: Abrupt changes in the global carbon cycle during the last glacial period, Nat. Geosci., 14, 91-96, https://doi.org/10.1038/s41561-020-006802, 2021.

Bennett, K.: Determination of the number of zones in a biostratigraphic sequence, New Phytol., 132, 155-170, 1996.

Bentley, M. J., Ó Cofaigh, C., Anderson, J. B., Conway, H., Davies, B., Graham, A. G. C., Hillenbrand, C.-D., Hodgson, D. A., Jamieson, S. S. R., Larter, R. D., Mackintosh, A., Smith, J. A., Verleyen, E., Ackert, R. P., Bart, P. J., Berg, S., Brunstein, D., Canals, M., Colhoun, E. A., Crosta, X., Dickens, W. A., Domack, E., Dowdeswell, J. A., Dunbar, R., Ehrmann, W., Evans, J., Favier, V., Fink, D., Fogwill, C. J., Glasser, N. F., Gohl, K., Golledge, N. R., Goodwin, I., Gore, D. B., Greenwood, S. L., Hall, B. L., Hall, K., Hedding, D. W., Hein, A. S., Hocking, E. P., Jakobsson, M., Johnson, J. S., Jomelli, V., Jones, R. S., Klages, J. P., Kristoffersen, Y., Kuhn, G., Leventer, A., Licht, K., Lilly, K., Lindow, J., Livingstone, S. J., Massé, G., McGlone, M. S., McKay, R. M., Melles, M., Miura, H., Mulvaney, R.,
Nel, W., Nitsche, F. O., O’Brien, P. E., Post, A. L., Roberts, S. J., Saunders, K. M., Selkirk, P. M., Simms, A. R., Spiegel, C., Stolldorf, T. D., Sugden, D. E., van der Putten, N., van Ommen, T., Verfaillie, D., Vyverman, W., Wagner, B., White, D. A., Witus, A. E., and Zwartz, D.: A community-based geological reconstruction of Antarctic Ice Sheet deglaciation since the Last Glacial Maximum, Quaternary Sci. Rev., 100, 1-9, https://doi.org/10.1016/j.quascirev.2014.06.025, 2014.

Benz, V., Esper, O., Gersonde, R., Lamy, F., and Tiedemann, R.: Last Glacial Maximum sea surface temperature and sea-ice extent in the Pacific sector of the Southern Ocean, Quaternary Sci. Rev., 146, 216-237, https://doi.org/10.1016/j.quascirev.2016.06.006, 2016.

Berg, S., Melles, M., Hermichen, W.-D., McClymont, E. L., Bentley, M. J., Hodgson, D. A., and Kuhn, G.: Evaluation of Mumiyo Deposits From East Antarctica as Archives for the Late Quaternary Environmental and Climatic History, Geochemistry, Geophysics, Geosystems, 20, 260-276, https://doi.org/10.1029/2018GC008054, 2019.

Bierman, W. H. and Voous, K. H.: Birds observed and collected during the whaling expedition of the "Willem Barendz" in the Antarctic 1946-1947, Ardea, 37, 1-123, 1950.

Björck, S., Hjort, C., Ingólfsson, O., and Skog, G.: Radiocarbon dates from the Antarctic Peninsula - problems and potential, in: Radiocarbon Dating: Recent Applications and Future Potential, edited by: Lowe, J. J., Quaternary Research Association, Cambridge, 55-65, ISSN 0963-1895, 1991.

Bonn, W. J., Gingele, F. X., Grobe, H., Mackensen, A., and Fütterer, D. K.: Palaeoproductivity at the Antarctic continental margin: opal and barium records for the last $400 \mathrm{ka}$, Palaeogeogr. Palaeocl., 139, 195-211, 1998.

Bostock, H. C., Opdyke, B. N., Gagan, M. K., and Fifield, L. K.: Carbon isotope evidence for changes in Antarctic Intermediate Water circulation and ocean ventilation in the southwest Pacific during the last deglaciation, Paleoceanography, 19, PA001047, https://doi.org/10.1029/2004PA001047, 2004.

Bottino, N. R.: Lipid composition of two species of antarctic krill: Euphausia superba and E. crystallorophias, Comp. Biochem. Phys. B, 50, 479-484, https://doi.org/10.1016/03050491(75)90261-8, 1975.

Bouttes, N., Roche, D. M., Paillard, D., Brovkin, V., and Bopp, L.: Last Glacial Maximum $\mathrm{CO}_{2}$ and $\delta^{13} \mathrm{C}$ successfully reconciled, Geophys. Res. Lett., 38, L02705, https://doi.org/10.1029/2010GL044499, 2011.

Bridges, C., Savel, A., Stöcker, W., J., M., and Linzen, B.: Structure and function of krill (Euphausia superba) haemocyanin adaptation to life at low temperature, Life Chem. Rep. Suppl., 1, 353-356, 1983.

Cherel, Y., Fontaine, C., Richard, P., and Labatc, J.-P.: Isotopic niches and trophic levels of myctophid fishes and their predators in the Southern Ocean, Limnol. Oceanogr., 55, 324-332, https://doi.org/10.4319/lo.2010.55.1.0324, 2010.

Cherel, Y., Koubbi, P., Giraldo, C., Penot, F., Tavernier, E., Moteki, M., Ozouf-Costaz, C., Causse, R., Chartier, A., and Hosie, G.: Isotopic niches of fishes in coastal, neritic and oceanic waters off Adélie land, Antarctica, Polar Sci., 5, 286-297, https://doi.org/10.1016/j.polar.2010.12.004, 2011.

Collins, L. G., Pike, J., Allen, C. S., and Hodgson, D. A.: High-resolution reconstruction of southwest Atlantic 
sea-ice and its role in the carbon cycle during marine isotope stages 3 and 2, Paleoceanography, 27, PA3217, https://doi.org/10.1029/2011pa002264, 2012.

Collins, M., Knutti, R., Arblaster, J., Dufresne, J.-L., Fichefet, T., Friedlingstein, P., Gao, X., Gutowski, W. J., Johns, T., Krinner, G., Shongwe, M., Tebaldi, C., Weaver, A. J., and Wehner, M.: Long-term Climate Change: Projections, Commitments and Irreversibility, in: Climate Change 2013: The Physical Science Basis. Contribution of Working Group I to the Fifth Assessment Report of the Intergovernmental Panel on Climate Change edited by: Stocker, T. F., Qin, D., Plattner, G.-K., Tignor, M., Allen, S. K., Boschung, J., Nauels, A., Xia, Y., Bex, V., and Midgley, P. M., Cambridge University Press, Cambridge, United Kingdom and New York, NY, USA, ISBN 9781107661820, 2013.

Connan, M., Cherel, Y., and Mayzaud, P.: Lipids from stomach oil of procellariiform seabirds document the importance of myctophid fish in the Southern Ocean, Limnol. Oceanogr., 52, 24452455, 2007.

Cripps, G. C., Watkins, J. L., Hill, H. J., and Atkinson, A.: Fatty acid content of Antarctic krill Euphausia superba at South Georgia related to regional populations and variations in diet, Mar. Ecol. Prog. Ser., 181, 177-188, 1999.

Crosta, X. and Shemesh, A.: Reconciling down core anticorrelation of diatom carbon and nitrogen isotopic ratios from the Southern Ocean, Paleoceanography, 17, 10-11-10-18, https://doi.org/10.1029/2000pa000565, 2002.

Croudace, I. W., Rindby, A., and Rothwell, R. G.: ITRAX: Description and evaluation of a new sediment core scanner, in: New techniques in sediment core analysis, edited by: Rothwell, R. G., Geological Society Special Publication, 267, 51-63, https://doi.org/10.1144/GSL.SP.2006.267, 2006.

Delille, B., Vancoppenolle, M., Geilfus, N.-X., Tilbrook, B., Lannuzel, D., Schoemann, V., Becquevort, S., Carnat, G., Delille, D., Lancelot, C., Chou, L., Dieckmann, G. S., and Tison, J.-L.: Southern Ocean $\mathrm{CO}_{2}$ sink: The contribution of the sea ice, J. Geophys. Res.-Oceans, 119, 6340-6355, https://doi.org/10.1002/2014JC009941, 2014.

Delmont, T. O., Hammar, K. M., Ducklow, H. W., Yager, P. L., and Post, A. F.: Phaeocystis antarctica blooms strongly influence bacterial community structures in the Amundsen Sea polynya, Front. Microbiol., 5, 646, https://doi.org/10.3389/fmicb.2014.00646, 2014.

Delord, K., Pinet, P., Pinaud, D., Barbraud, C., De Grissac, S., Lewden, A., Cherel, Y., and Weimerskirch, H.: Species-specific foraging strategies and segregation mechanisms of sympatric Antarctic fulmarine petrels throughout the annual cycle, Ibis, 158, 569-586, https://doi.org/10.1111/ibi.12365, 2016.

Dunbar, R. B. and Leventer, A.: Seasonal variation in carbon isotopic composition of antarctic sea ice and open-water plankton communities, Antarct. J. US, 27, 79-81, 1992.

Falla, R. A.: Birds, in: Volume 2 of Reports of the B.A.N.Z. antarctic research expedition 1929-1931 / Series B, B.A.N.Z.A.R. Expedition Committee, 1937.

Färber Lorda, J. and Ceccaldi, H. J.: Relationship of morphometrics, total carotenoids, and total lipids with activity and sexual and spatial features in Euphausia superba, Sci. Rep., 10, 13177, https://doi.org/10.1038/s41598-020-69780-8, 2020.

Ferrari, R., Jansen, M. F., Adkins, J. F., Burke, A., Stewart, A. L., and Thompson, A. F.: Antarctic sea ice control on ocean circula- tion in present and glacial climates, P. Natl. Acad. Sci. USA, 111, 8753-8758, https://doi.org/10.1073/pnas.1323922111, 2014.

Fijn, R. C., van Franeker, J. A., and Trathan, P. N.: Dietary variation in chick-feeding and self-provisioning Cape Petrel Daption capense and Snow Petrel Pagodroma nivea at Signy Island, South Orkney Islands, Antarctica, Marine Ornithology, 40, 8187, 2012.

Fischer, H., Fundel, F., Ruth, U., Twarloh, B., Wegner, A., Udisti, R., Becagli, S., Castellano, E., Morganti, A., Severi, M., Wolff, E., Littot, G., Rothlisberger, R., Mulvaney, R., Hutterli, M. A., Kaufmann, P., Federer, U., Lambert, F., Bigler, M., Hansson, M., Jonsell, U., de Angelis, M., Boutron, C., Siggaard-Andersen, M.-L., Steffensen, J. P., Barbante, C., Gaspari, V., Gabrielli, P., and Wagenbach, D.: Reconstruction of millennial changes in dust emission, transport and regional sea ice coverage using the deep EPICA ice cores from the Atlantic and Indian Ocean sector of Antarctica, Earth Planet. Sc. Lett., 260, 340-354, 2007.

Francois, R., Altabet, M. A., Goericke, R., McCorkle, D. C., Brunet, C., and Poisson, A.: Changes in the $\delta^{13} \mathrm{C}$ of surface water particulate organic matter across the subtropical convergence in the SW Indian Ocean, Global Biogeochem. Cy., 7, 627-644, https://doi.org/10.1029/93GB01277, 1993.

Friedrich, C. and Hagen, W.: Lipid contents of five species of notothenioid fish from high-Antarctic waters and ecological implications, Polar Biol., 14, 359-369, https://doi.org/10.1007/BF00240256, 1994.

Frölicher, T. L., Joos, F., and Raible, C. C.: Sensitivity of atmospheric $\mathrm{CO}_{2}$ and climate to explosive volcanic eruptions, Biogeosciences, 8, 2317-2339, https://doi.org/10.5194/bg-8-23172011, 2011.

Gersonde, R., Abelmann, A., Brathauer, U., Becquey, S., Bianchi, C., Cortese, G., Grobe, H., Kuhn, G., Niebler, H.-S., Segl, M., Sieger, R., Zielinski, U., and Fütterer, D. K.: Last glacial sea surface temperatures and sea-ice extent in the Southern Ocean (Atlantic-Indian Sector): A multiproxy approach, Paleoceanography, 18, 1061, https://doi.org/10.1016/j.quascirev.2004.07.015, 2003.

Gersonde, R., Crosta, X., Abelmann, A., and Armand, L.: Seasurface temperature and sea ice distribution of the Southern Ocean at the EPILOG Last Glacial Maximum-a circumAntarctic view based on siliceous microfossil records, Quaternary Sci. Rev., 24, 869-896, 2005.

Goto-Azuma, K., Hirabayashi, M., Motoyama, H., Miyake, T., Kuramoto, T., Uemura, R., Igarashi, M., Iizuka, Y., Sakurai, T., Horikawa, S., Suzuki, K., Suzuki, T., Fujita, K., Kondo, Y., Hattori, S., and Fujii, Y.: Reduced marine phytoplankton sulphur emissions in the Southern Ocean during the past seven glacials, Nat. Commun., 10, 3247, https://doi.org/10.1038/s41467-01911128-6, 2019.

Grobe, H. and Mackensen, A.: Late Quaternary climatic cycles as recorded in sediments from the Antarctic continental margin, in: The Antarctic Paleoenvironment: a Perspective on Global Change, edited by: Kennett, J. P., and Warnke, D. A., Antarctic Research Series vol. 56, American Geophysical Union, Washington, DC, 349-376, ISBN 9781118668061, 1993.

Hammer, Ø., Harper, D. A. T., and Ryan, P. D.: PAST: Paleontological Statistics Software Package for Education and Data Analysis, Palaeontol. Electron., 4, 9 pp., https://palaeo-electronica.org/ 2001_1/past/past.pdf (last access: 1 March 2022), 2001. 
Harris, P. G. and Maxwell, J. R.: A novel method for the rapid determination of chlorin concentrations at high stratigraphic resolution in marine sediments, Org. Geochem., 23, 853-856, 1995.

Heaton, T. J., Bard, E., Bronk Ramsey, C., Butzin, M., Kohler, P., and Reimer, P. J.: Community comment on "Summer sea-ice variability on the Antarctic margin during the last glacial period reconstructed from snow petrel (Pagodroma nivea) stomachoil deposits" by Erin L. McClymont et al., Clim. Past Discuss., https://doi.org/10.5194/cp-2021-134-CC1, 2021.

Heaton, T. J., Köhler, P., Butzin, M., Bard, E., Reimer, R. W., Austin, W. E. N., Bronk Ramsey, C., Grootes, P. M., Hughen, K. A., Kromer, B., Reimer, P. J., Adkins, J., Burke, A., Cook, M. S., Olsen, J., and Skinner, L. C.: Marine20-The Marine Radiocarbon Age Calibration Curve (0-55000 cal BP), Radiocarbon, 62, 779-820, https://doi.org/10.1017/RDC.2020.68, 2020.

Henley, S. F., Annett, A. L., Ganeshram, R. S., Carson, D. S., Weston, K., Crosta, X., Tait, A., Dougans, J., Fallick, A. E., and Clarke, A.: Factors influencing the stable carbon isotopic composition of suspended and sinking organic matter in the coastal Antarctic sea ice environment, Biogeosciences, 9, 1137-1157, https://doi.org/10.5194/bg-9-1137-2012, 2012.

Hillenbrand, C.-D. and Cortese, G.: Polar stratification: A critical view from the Southern Ocean, Palaeogeogr. Palaeocl., 242, 240-252, https://doi.org/10.1016/j.palaeo.2006.06.001, 2006.

Hillenbrand, C.-D., Bentley, M. J., Stolldorf, T. D., Hein, A. S., Kuhn, G., Graham, A. G. C., Fogwill, C. J., Kristoffersen, Y., Smith, J. A., Anderson, J. B., Larter, R. D., Melles, M., Hodgson, D. A., Mulvaney, R., and Sugden, D. E.: Reconstruction of changes in the Weddell Sea sector of the Antarctic Ice Sheet since the Last Glacial Maximum, Quaternary Sci. Rev., 100, 111-136, https://doi.org/10.1016/j.quascirev.2013.07.020, 2014.

Hiller, A., Wand, U., Kampft, H., and Stackebrandt, W.: Occupation of the Antarctic Continent by Petrels During the Past 35000 Years: Inferences from a ${ }^{14} \mathrm{C}$ Study of Stomach Oil Deposits, Polar Biol., 9, 69-77, 1988.

Hiller, A., Hermichen, W.-D., and Wand, U.: Radiocarbon-dated subfossil stomach oil deposits from petrel nesting sites: novel paleoenvironmental records from continental Antarctica, Radiocarbon, 37, 171-180, 1995.

Horgan, I. E. and Barrett, J. A.: The Use of Lipid Profiles in Comparing the Diet of Seabirds, in: Antarctic Nutrient Cycles and Food Webs, edited by: Siegfried, W. R., Condy, P. R., and Laws, R. M., Springer Berlin Heidelberg, Berlin, Heidelberg, 493-497, ISBN 9783642822773, 1985.

Huang, T., Sun, L., Wang, Y., Liu, X., and Zhu, R.: Penguin population dynamics for the past 8500 years at Gardner Island, Vestfold Hills, Antarct. Sci., 21, 571-578, https://doi.org/10.1017/S0954102009990332, 2009.

Imber, M. J.: The Origin of Petrel Stomach Oils: A Review, Condor, 78, 366-369, https://doi.org/10.2307/1367697, 1976.

Jaeger, A. and Cherel, Y.: Isotopic Investigation of Contemporary and Historic Changes in Penguin Trophic Niches and Carrying Capacity of the Southern Indian Ocean, PLOS ONE, 6, e16484, https://doi.org/10.1371/journal.pone.0016484, 2011.

Jeffrey, S. W., Mantoura, R. F. C., and Bjørnland, T.: Data for the identification of 47 key phytoplankton pigments, in: Phytoplankton pigments in oceanography: guidelines to modern methods, edited by: Jeffrey, S. W., Mantoura, R. F. C., and Wright, S. W., UNESCO Publishing, Paris, ISBN 9231032755, 149-559, 1997.
Johansson, P. and Thor, G.: Observations on the birds of the Vestfjella and Heimefrontfjella, Dronning Maud Land, Antarctica, 1991/92 and 2001/02, Marine Ornithology, 32, 43-46, 2004.

Jónasdóttir, S. H.: Fatty Acid Profiles and Production in Marine Phytoplankton, Mar. Drugs, 17, 151, https://doi.org/10.3390/md17030151, 2019.

Jouzel, J., Masson-Delmotte, V., Cattani, O., Dreyfus, G., Falourd, S., Hoffmann, G., Minster, B., Nouet, J., Barnola, J. M., Chappellaz, J., Fischer, H., Gallet, J. C., Johnsen, S., Leuenberger, M., Loulergue, L., Luethi, D., Oerter, H., Parrenin, F., Raisbeck, G., Raynaud, D., Schilt, A., Schwander, J., Selmo, E., Souchez, R., Spahni, R., Stauffer, B., Steffensen, J. P., Stenni, B., Stocker, T. F., Tison, J. L., Werner, M., and Wolff, E. W.: Orbital and Millennial Antarctic Climate Variability over the Past 800,000 Years, Science, 317, 793-796, 2007.

Ju, S.-J. and Harvey, H. R.: Lipids as markers of nutritional condition and diet in the Antarctic krill Euphausia superba and Euphausia crystallorophias during austral winter, Deep-Sea Res. Pt. II, 51, 2199-2214, https://doi.org/10.1016/j.dsr2.2004.08.004, 2004.

Juggins, S.: rioja: Analysis of Quaternary Science Data, R package version 0.9-26, CRAN, https://cran.r-project.org/package=rioja (last access: 17 February 2022), 2020.

Karnovsky, N., Ainley, D. G., and Lee, P.: Chapter 12 The Impact and Importance of Production in Polynyas to Top-Trophic Predators: Three Case Histories, in: Polynyas: Windows to the World, edited by: Smith, W. O. and Barber, D. G., Elsevier, 391-410, ISBN: 9780444529527, 2007.

Kennedy, H., Thomas, D., Kattner, G., Haas, C., and Dieckmann, G.: Particulate organic matter in Antarctic summer sea ice: Concentration and stable isotopic composition, Mar. Ecol. Prog. Ser., 238, 1-13, 2002.

La, H. S., Lee, H., Fielding, S., Kang, D., Ha, H. K., Atkinson, A., Park, J., Siegel, V., Lee, S., and Shin, H. C.: High density of ice krill (Euphausia crystallorophias) in the Amundsen sea coastal polynya, Antarctica, Deep-Sea Res. Pt. I, 95, 75-84, https://doi.org/10.1016/j.dsr.2014.09.002, 2015.

Lee, H., Feakins, S. J., Lu, Z., Schimmelmann, A., Sessions, A. L., Tierney, J. E., and Williams, T. J.: Comparison of three methods for the methylation of aliphatic and aromatic compounds, Rapid Commun. Mass Spectrom., 31, 1633-1640, https://doi.org/10.1002/rcm.7947, 2017.

Lee, R. F., Nevenzel, J. C., and Paffenhöfer, G. A.: Importance of wax esters and other lipids in the marine food chain: Phytoplankton and copepods, Mar. Biol., 9, 99-108, https://doi.org/10.1007/BF00348249, 1971.

Leri, A. C., Hakala, J. A., Marcus, M. A., Lanzirotti, A., Reddy, C. M., and Myneni, S. C. B.: Natural organobromine in marine sediments: New evidence of biogeochemical Br cycling, Global Biogeochem. Cy., 24, 2010GB003794, https://doi.org/10.1029/2010GB003794, 2010.

Lewis, R. W.: Studies of the glyceryl ethers of the stomach oil of Leach's petrel Oceanodroma leucorhoa (Viellot), Comp. Biochem. Physiol., 19, 363-377, 1966.

Liu, X., Nie, Y., Sun, L., and Emslie, S. D.: Eco-environmental implications of elemental and carbon isotope distributions in ornithogenic sediments from the Ross Sea region, Antarctica, Geochim. Cosmochim. Ac., 117, 99-114, https://doi.org/10.1016/j.gca.2013.04.013, 2013. 
Lucchi, R. G., Rebesco, M., Camerlenghi, A., Busetti, M., Tomadin, L., Villa, G., Persico, D., Morigi, C., Bonci, M. C., and Giorgetti, G.: Mid-late Pleistocene glacimarine sedimentary processes of a high-latitude, deep-sea sediment drift (Antarctic Peninsula Pacific margin), Mar. Geol., 189, 343-370, https://doi.org/10.1016/S0025-3227(02)00470-X, 2002.

Mackensen, A., Grobe, H., Hubberton, H.-W., Spiess, V., and Futterer, D. K.: Stable isotope stratigraphy from the Antarctic continental margin during the last one million years, Mar. Geol., 87, 315-321, 1989.

Mackintosh, A. N., Verleyen, E., O'Brien, P. E., White, D. A., Jones, R. S., McKay, R., Dunbar, R., Gore, D. B., Fink, D., Post, A. L., Miura, H., Leventer, A., Goodwin, I., Hodgson, D. A., Lilly, K., Crosta, X., Golledge, N. R., Wagner, B., Berg, S., van Ommen, T., Zwartz, D., Roberts, S. J., Vyverman, W., and Masse, G.: Retreat history of the East Antarctic Ice Sheet since the Last Glacial Maximum, Quaternary Sci. Rev., 100, 10-30, https://doi.org/10.1016/j.quascirev.2013.07.024, 2014.

Marchant, S. and Higgins, R. J. (Eds.): Handbook of Australian, New Zealand and Antarctic Birds. Volume 1 Part A, Ratites to petrels, Oxford University Press, Melbourne, 735, ISBN $0195532449,1990$.

Marzocchi, A., and Jansen, M. F.: Global cooling linked to increased glacial carbon storage via changes in Antarctic sea ice, Nat. Geosci., 12, 1001-1005, https://doi.org/10.1038/s41561019-0466-8, 2019.

Mayzaud, P., Chevallier, J., Tavernier, E., Moteki, M., and Koubbi, P.: Lipid composition of the Antarctic fish Pleuragramma antarcticum. Influence of age class, Polar Sci., 5, 264-271, https://doi.org/10.1016/j.polar.2010.12.003, 2011.

McClymont, E. L., Martinez-Garcia, A., and Rosell-Mele, A.: Benefits of freeze-drying sediments for the analysis of total chlorins and alkenone concentrations in marine sediments, Org. Geochem., 38, 1002-1007, https://doi.org/10.1016/j.orggeochem.2007.01.006, 2007.

McClymont, E. L., Bentley, M. J., Hodgson, D. A., SpencerJones, C. L, Wardley, T., West, M., Croudace, I. W., Berg, S., Gröcke, D. R., Kuhn, G., Jamieson, S., Sime, L. C., and Phillips, R. A.: Age model, XRF data, fatty acid distributions and stable isotope analysis for stomach oil deposit WMM7, Dronning Maud Land, PANGAEA [data set], https://doi.org/10.1594/PANGAEA.939211, 2021.

Menviel, L., Mouchet, A., Meissner, K. J., Joos, F., and England, M. H.: Impact of oceanic circulation changes on atmospheric $\delta^{13} \mathrm{CO}_{2}$, Global Biogeochem. Cy., 29, 1944-1961, https://doi.org/10.1002/2015GB005207, 2015.

Mills, W. F., Xavier, J. C., Bearhop, S., Cherel, Y., Votier, S. C., Waluda, C. M., and Phillips, R. A.: Long-term trends in albatross diets in relation to prey availability and breeding success, Mar. Biol., 167, 29, https://doi.org/10.1007/s00227-019-3630-1, 2020.

Mills, W. F., Morley, T. I., Votier, S. C., and Phillips, R. A.: Longterm inter- and intraspecific dietary variation in sibling seabird species, Mar. Biol., 168, 31, https://doi.org/10.1007/s00227-02103839-6, 2021.

Mohrmann, M., Heuzé, C., and Swart, S.: Southern Ocean polynyas in CMIP6 models, The Cryosphere, 15, 4281-4313, https://doi.org/10.5194/tc-15-4281-2021, 2021.
Morales Maqueda, M. A. and Rahmstorf, S.: Did Antarctic sea-ice expansion cause glacial $\mathrm{CO}_{2}$ decline?, Geophys. Res. Lett., 29, 11-11-11-13, https://doi.org/10.1029/2001GL013240, 2002.

Morales Maqueda, M. A., Willmott, A. J., and Biggs, N. R. T.: Polynya Dynamics: a Review of Observations and Modeling, Rev. Geophys., 42, RG1004, https://doi.org/10.1029/2002RG000116, 2004.

Mychra, A. and Tatur, A.: Ecological role of the current and abandoned penguin rookeries in the land environment of the maritime Antarctic, Pol. Polar Res., 12, 3-24, 1991.

Nicol, S.: A comparison of Antarctic petrel (Thalassoica antarctica) diets with net samples of Antarctic krill (Euphausia superba) taken from the Prydz Bay region, Polar Biol., 13, 399-403, 1993.

Nicol, S.: Krill, Currents, and Sea Ice: Euphausia superba and Its Changing Environment, BioScience, 56, 111-120, https://doi.org/10.1641/00063568(2006)056[0111:KCASIE]2.0.CO;2, 2006.

Olivier, F. and Wotherspoon, S. J.: Modelling habitat selection using presence-only data: Case study of a colonial hollow nesting bird, the snow petrel, Ecol. Model., 195, 187-204, https://doi.org/10.1016/j.ecolmodel.2005.10.036, 2006.

Olivier, F., van Franeker, J. A., Creuwels, J. C. S., and Woehler, E. J.: Variations of snow petrel breeding success in relation to sea-ice extent: detecting local response to large-scale processes?, Polar Biol., 28, 687-699, 2005.

Paillard, D. and Parrenin, F.: The Antarctic ice sheet and the triggering of deglaciations, Earth Planet. Sc. Lett., 227, 263-271, 2004

Palmer Locarnini, S. J. and Presley, B. J.: Trace element concentrations in Antarctic krill, Euphausia superba, Polar Biol., 15, 283-288, https://doi.org/10.1007/BF00239849, 1995.

Parkinson, C. L.: A 40-y record reveals gradual Antarctic sea ice increases followed by decreases at rates far exceeding the rates seen in the Arctic, P. Natl. Acad. Sci. USA, 116, 14414-14423, https://doi.org/10.1073/pnas.1906556116, 2019.

Phillips, R. A., Bearhop, S., McGill, R. A., and Dawson, D. A.: Stable isotopes reveal individual variation in migration strategies and habitat preferences in a suite of seabirds during the nonbreeding period, Oecologia, 160, 795-806, https://doi.org/10.1007/s00442-009-1342-9, 2009.

Phillips, R. A., McGill, R. A. R., Dawson, D. A., and Bearhop, S.: Sexual segregation in distribution, diet and trophic level of seabirds: insights from stable isotope analysis, Mar. Biol., 158, 2199-2208, 2011.

Polito, M. J., Trivelpiece, W. Z., Karnovsky, N. J., Ng, E., Patterson, W. P., and Emslie, S. D.: Integrating Stomach Content and Stable Isotope Analyses to Quantify the Diets of Pygoscelid Penguins, PLOS ONE, 6, e26642, https://doi.org/10.1371/journal.pone.0026642, 2011.

Post, D. M.: Using Stable Isotopes to Estimate Trophic Position: Models, Methods, and Assumptions, Ecology, 83, 703-718, https://doi.org/10.2307/3071875, 2002.

Quillfeldt, P. and Masello, J. F.: Compound-specific stable isotope analyses in Falkland Islands seabirds reveal seasonal changes in trophic positions, BMC Ecology, 20, 21, https://doi.org/10.1186/s12898-020-00288-5, 2020.

Raclot, T., Groscolas, R., and Cherel, Y.: Fatty acid evidence for the importance of myctophid fishes in the diet of king penguins, Aptenodytes patagonicus, Mar. Biol., 132, 523-533, https://doi.org/10.1007/s002270050418, 1998. 
Rae, J. W. B., Burke, A., Robinson, L. F., Adkins, J. F., Chen, T., Cole, C., Greenop, R., Li, T., Littley, E. F. M., Nita, D. C., Stewart, J. A., and Taylor, B. J.: $\mathrm{CO}_{2}$ storage and release in the deep Southern Ocean on millennial to centennial timescales, Nature, 562, 569-573, https://doi.org/10.1038/s41586-018-0614-0, 2018.

Rainbow, P. S.: Copper, cadmium and zinc concentrations in oceanic amphipod and euphausiid crustaceans, as a source of heavy metals to pelagic seabirds, Mar. Biol., 103, 513-518, https://doi.org/10.1007/BF00399583, 1989.

Rau, G. H., Ainley, D. G., Bengtson, J. L., Torres, J. J., and Hopkins, T. L.: ${ }^{15} \mathrm{~N} /{ }^{14} \mathrm{~N}$ and ${ }^{13} \mathrm{C} /{ }^{12} \mathrm{C}$ in Weddell Sea birds, seals, and fish: implications for diet and trophic structure, Mar. Ecol. Prog. Ser., 84, 1-8, 1992.

Rethemeyer, J., Gierga, M., Heinze, S., Stolz, A., Wotte, A., Wischhöfer, P., Berg, S., Melchert, J., and Dewald, A.: Current sample preparation and analytical capabilities of the radiocarbon laboratory at CologneAMS, Radiocarbon, 61, 1449-1460, https://doi.org/10.1017/RDC.2019.16, 2019.

Ridoux, V. and Offredo, C.: The diets of five summer breeding seabirds in Adélie Land, Antarctica, Polar Biol., 9, 137-145, https://doi.org/10.1007/bf00297168, 1989.

Roche, D. M., Crosta, X., and Renssen, H.: Evaluating Southern Ocean sea-ice for the Last Glacial Maximum and pre-industrial climates: PMIP-2 models and data evidence, Quaternary Sci. Rev., 56, 99-106, https://doi.org/10.1016/j.quascirev.2012.09.020, 2012.

Saunders, R. A., Hill, S. L., Tarling, G. A., and Murphy, E. J.: Myctophid Fish (Family Myctophidae) Are Central Consumers in the Food Web of the Scotia Sea (Southern Ocean), Frontiers in Marine Science, 6, 530, https://doi.org/10.3389/fmars.2019.00530, 2019.

Seyboth, E., Botta, S., Mendes, C. R. B., Negrete, J., Dalla Rosa, L., and Secchi, E. R.: Isotopic evidence of the effect of warming on the northern Antarctic Peninsula ecosystem, Deep Sea Res. Pt. II, 149, 218-228, 2018.

Sherrell, R., Lagerström, M., Forsch, K., Stammerjohn, S., and Yager, P.: Dynamics of dissolved iron and other bioactive trace metals $(\mathrm{Mn}, \mathrm{Ni}, \mathrm{Cu}, \mathrm{Zn})$ in the Amundsen Sea Polynya, Antarctica, Elementa, 3, 000071, https://doi.org/10.12952/journal.elementa.000071, 2015.

Sigman, D. M., Fripiat, F., Studer, A. S., Kemeny, P. C., MartínezGarcía, A., Hain, M. P., Ai, X., Wang, X., Ren, H., and Haug, G. H.: The Southern Ocean during the ice ages: A review of the Antarctic surface isolation hypothesis, with comparison to the North Pacific, Quaternary Sci. Rev., 254, 106732, https://doi.org/10.1016/j.quascirev.2020.106732, 2021.

Smith, J. A., Hillenbrand, C.-D., Pudsey, C. J., Allen, C. S., and Graham, A. G. C.: The presence of polynyas in the Weddell Sea during the Last Glacial Period with implications for the reconstruction of sea-ice limits and ice sheet history, Earth Planet. Sc. Lett., 296, 287-298, https://doi.org/10.1016/j.epsl.2010.05.008, 2010.

Sprenk, D., Weber, M. E., Kuhn, G., Wennrich, V., Hartmann, T., and Seelos, K.: Seasonal changes in glacial polynya activity inferred from Weddell Sea varves, Clim. Past, 10, 1239-1251, https://doi.org/10.5194/cp-10-1239-2014, 2014.
Steele, W. K.: Stable isotope ratios of Antarctic petrel (Thallassoica antarctica) and snow petrel (Pagodroma nivea) bone collagen, Polar Biol., 28, 672-679, 2005.

Stephens, B. B. and Keeling, R. F.: The influence of Antarctic sea ice on glacial-interglacial $\mathrm{CO}_{2}$ variations, Nature, 404, 171-174, 2000.

Thatje, S., Hillenbrand, C.-D., Mackensen, A., and Larter, R.: Life Hung by a Thread: Endurance of Antarctic Fauna in Glacial Periods, Ecology, 89, 682-692, 2008.

Thor, G. and Low, M.: The persistence of the snow petrel (Pagodroma nivea) in Dronning Maud Land (Antarctica) for over 37000 years, Polar Biol., 34, 609-613, https://doi.org/10.1007/s00300-010-0912-y, 2011.

Tierney, J. E., Zhu, J., King, J., Malevich, S. B., Hakim, G. J., and Poulsen, C. J.: Glacial cooling and climate sensitivity revisited, Nature, 584, 569-573, https://doi.org/10.1038/s41586-0202617-x, 2020.

Trull, T. W. and Armand, L.: Insights into Southern Ocean carbon export from the $\delta^{13} \mathrm{C}$ of particles and dissolved inorganic carbon during the SOIREE iron release experiment, DeepSea Res. Pt. II, 48, 2655-2680, https://doi.org/10.1016/S09670645(01)00013-3, 2001.

Turner, J., Guarino, M. V., Arnatt, J., Jena, B., Marshall, G. J., Phillips, T., Bajish, C. C., Clem, K., Wang, Z., Andersson, T., Murphy, E. J., and Cavanagh, R.: Recent Decrease of Summer Sea Ice in the Weddell Sea, Antarctica, Geophys. Res. Lett., 47, e2020GL087127, https://doi.org/10.1029/2020GL087127, 2020.

Vallet, C., Beans, C., Koubbi, P., Courcot, L., Hecq, J.-H., and Goffart, A.: Food preferences of larvae of Antarctic silverfish Pleuragramma antarcticum Boulenger, 1902 from Terre Adélie coastal waters during summer 2004, Polar Sci., 5, 239-251, https://doi.org/10.1016/j.polar.2010.12.005, 2011.

Wand, U. and Hermichen, W.-D.: Late Quaternary Ice Level Changes in Central Dronning Maud Land, East Antarctica, as Inferred from ${ }^{14} \mathrm{C}$ ages of Mumiyo Deposits in Snow Petrel Colonies, Geol. Jahrbuch, B97, 237-254, 2005.

Wang, S. W., Iverson, S. J., Springer, A. M., and Hatch, S. A.: Fatty acid signatures of stomach oil and adipose tissue of northern fulmars (Fulmarus glacialis) in Alaska: implications for diet analysis of Procellariiorm birds, J. Comp. Physiol. B, 177, 893-903, 2007.

Warham, J.: The incidence, functions and ecological significance of petrel stomach oils, Proceedings of the New Zealand Ecological Society, 24, 84-93, 1977.

Warham, J., Watts, R., and Dainty, R. J.: The composition, energy content and function of the stomach oils of petrels (order, Procellariiformes), J. Exp. Mar. Biol. Ecol., 23, 1-13, 1976.

Watanabe, Y. Y., Ito, K., Kokubun, N., and Takahashi, A.: Foraging behavior links sea ice to breeding success in Antarctic penguins, Sci. Adv., 6, eaba4828, https://doi.org/10.1126/sciadv.aba4828, 2020.

Watanuki, Y. and Thiebot, J.-B.: Factors affecting the importance of myctophids in the diet of the world's seabirds, Mar. Biol., 165, 79, https://doi.org/10.1007/s00227-018-3334-y, 2018.

Watts, R. and Warham, J.: Structure of some intact lipids of petrel stomach oils, Lipids, 11, 423-429, https://doi.org/10.1007/bf02532831, 1976. 
Weber, M. E., Bonani, G., and Fütterer, K. D.: Sedimentation processes within channel-ridge systems, southeastern Weddell Sea, Antarctica, Paleoceanography, 9, 1027-1048, 1994.

Xiao, W., Esper, O., and Gersonde, R.: Last Glacial Holocene climate variability in the Atlantic sector of the Southern Ocean, Quaternary Sci. Rev., 135, 115-137, https://doi.org/10.1016/j.quascirev.2016.01.023, 2016. 